\title{
Resistance to Tomato yellow leaf curl virus Accumulation in the Tomato Wild Relative Solanum habrochaites Associated with the C4 Viral Protein
}

\author{
Diego M. Tomás, ${ }^{1}$ M. Carmen Cañizares, ${ }^{1}$ Jesús Abad, ${ }^{2}$ Rafael Fernández-Muñoz,, and Enrique Moriones ${ }^{1}$ \\ ${ }^{1}$ Instituto de Hortofruticultura Subtropical y Mediterránea "La Mayora", Consejo Superior de Investigaciones Científicas \\ (IHSM-UMA-CSIC), Estación Experimental “La Mayora”, E-29750 Algarrobo-Costa, Málaga, Spain; ² Zeta Vegetable Seeds, \\ El Ejido, Almería, Spain
}

Submitted 30 December 2010. Accepted 5 March 2011.

Tomato yellow leaf curl disease (TYLCD) is a severe threat to tomato crops worldwide and is caused by Tomato yellow leaf curl virus (TYLCV) and several other begomoviruses (genus Begomovirus, family Geminiviridae). Host plant resistance is the best TYLCD control method but limited sources of resistance are available. In this study, two Solanum habrochaites TYLCD-resistance sources, EELM-388 and EELM-889, were found after a wide germplasm screening and were further characterized. A consistent resistance to the widely distributed strain TYLCV-IL was observed when plants were inoculated by Bemisia tabaci or by agroinoculation using an infectious clone, with no symptoms or virus accumulation observed in inoculated plants. Moreover, the resistance was effective under field conditions with high TYLCD pressure. Two independent loci, one dominant and one recessive, were associated with EELM889 resistance. The study shows these loci to be distinct from that of the resistance gene (Ty-1 gene) commonly deployed in commercial tomato cultivars. Therefore, both kinds of resistance could be combined to provide improved resistance to TYLCD. Four additional TYLCD-associated viruses were challenged, showing that the resistance always prevented symptom expression, although systemic infection could occur in some cases. By using chimeric and mutant expression constructs, the $\mathrm{C} 4$ protein was shown to be associated with the ability to result in effective systemic infection.

Tomato yellow leaf curl disease (TYLCD) is one of the most devastating viral diseases of tomato (Solanum lycopersicum L.) worldwide (Hanssen et al. 2010; Moriones et al. 2011). This emerging disease is caused by isolates of several singlestranded DNA-containing geminiviruses (family Geminiviridae) in the genus Begomovirus, which are transmitted by the whitefly Bemisia tabaci Gennadius (Hemiptera:Aleyrodidae) in a persistent circulative manner (Czosnek et al. 2002). To infect host plants systemically, these viruses must first replicate via a double-stranded DNA intermediate in the plant cell nucleus; they then move out of the nucleus to the cytosol, move from cell to cell via plasmodesmata, and finally move throughout the plant via a phloem-mediated transport (Jeske

D. M. Tomás, and M. C. Cañizares contributed equally to this work.

Corresponding author: E. Moriones; Telephone: $(+34)$ 952548990; Fax: (+34) 952552677; E-mail: moriones@eelm.csic.es
2009; Wege 2007). Virus infection can be limited by a failure of the required interactions between plant and viral factors or by active host-defense responses. However, our understanding of the mechanisms controlling virus invasion of plants and of host factors involved in the process remains limited.

Currently, isolates of at least 11 different begomovirus species have been associated with TYLCD (Fauquet et al. 2008). Moreover, multiple species can contribute to the same epidemic; for example, TYLCD epidemics in the Mediterranean basin involve strains of at least four virus species (Davino et al. 2009; García-Andrés et al. 2006, 2007; Monci et al. 2002). The Israel strain of Tomato yellow leaf curl virus (TYLCV-IL), however, is the most widespread and economically important begomovirus species causing TYLCD (Cohen and Lapidot 2007; Lefeuvre et al. 2010; Moriones et al. 2011). All TYLCD-associated begomoviruses induce plant stunting and yellowing and upward curling of leaves in infected tomato. Tomato fruits are symptomless although they are sometimes smaller than normal; if infection occurs at an early growth stage, flower abortion can result in total yield loss (Picó et al. 1996).

Most of the TYLCD-associated viruses have monopartite genomes of approximately 2,800 nucleotides, with two genes on the virion-sense strand that encode the precoat and coat proteins (V2 and $\mathrm{CP}$, respectively) and four genes on the complementary-sense strand that encode the replication-associated, transcriptional activator, replication enhancer, and $\mathrm{C} 4$ proteins (Rep, TrAP, REn, and C4, respectively). Also, an intergenic region (IR) that contains key elements for replication and transcription (Argüello-Astorga et al. 1994) is present. The only protein required for virus replication is Rep (Gutiérrez 1999; Hanley-Bowdoin et al. 2000; Laufs et al. 1995), which interacts with REn (Castillo et al. 2003). TrAP is a host-range factor (Wartig et al. 1997) and, together with C4, functions as a pathogenicity determinant (Selth et al. 2004; van Wezel et al. 2001, 2002a). The open reading frame (ORF) of the C4 protein is contained in a different reading frame within the Rep coding region; protein $\mathrm{C} 4$ has been associated with symptom development (Krake et al. 1998; Selth et al. 2004) and, together with the CP and V2, with the movement of monopartite begomoviruses (Jupin et al. 1994; Rojas et al. 2001).

RNA silencing in plants operates as an antiviral defense response; to establish infection, viruses must suppress RNA silencing by the host (Díaz-Pendón and Ding 2008; Voinnet 2005). At least three RNA-silencing suppressors have been reported in TYLCD-associated or related begomoviruses. Thus, the V2 protein of TYLCV functions as an RNA-silenc- 
ing suppressor; it counteracts the innate immune response of the host plant by interacting with SISGS3, the tomato homolog of the Arabidopsis SGS3 protein involved in the RNA-silencing pathway (Glick et al. 2008). The TrAP protein of the related monopartite begomovirus. Tomato yellow leaf curl China virus is also involved in suppression of RNA silencing (van Wezel et al. 2002b), probably by activating transcription of host genes that control silencing (Trinks et al. 2005). The C4 protein of the monopartite begomoviruses. Tomato leaf curl virus (ToLCV), Ageratum yellow vein virus, and Bhendi yellow vein mosaic virus also have the ability to suppress RNA silencing (Dogra et al. 2009; Gopal et al. 2007; Sharma et al. 2010). Sequestration of small RNAs was associated with suppression of gene silencing by the related AC4 protein of the bipartite begomovirus. African cassava mosaic virus (ACMV) (Vanitharani et al. 2005).

Control of TYLCD is difficult and is mainly based on intensive insecticide treatments to control vector populations; this method of control has deleterious environmental consequences (Palumbo et al. 2001) and also has limited success because it selects for insecticide-resistant populations in $B$. tabaci (Cahill et al. 1996; Elbert and Nauen 2000). Crop management using physical barriers or UV-absorbing plastic films and screens in protected crops can also help control TYLCD (Antignus et al. 2001). Although the use of virusresistant cultivars is currently the best alternative for controlling TYLCD, limited sources of resistance useful at the commercial level are available, which greatly limits the possibility of crop breeding (Ji et al. 2007b; Lapidot and Friedmann 2002). Frequently, TYLCD resistance is under complex genetic control that is difficult to manage in breeding programs (Lapidot and Friedman 2002). The most widespread resistance used commercially is based on the partially dominant Ty- 1 resistance gene derived from the $S$. chilense (Dunal) Reiche accession LA1969 (Zamir et al. 1994). This resistance substantially reduces symptoms and virus accumulation in infected plants (Michelson et al. 1994) but can breakdown under high disease pressure (Lapidot and Friedmann 2002). The $T y-1$ gene may also select for virus strains (GarcíaAndrés et al. 2009), which eventually could result in resistance breaking (Seal et al. 2006). Additional TYLCD-resistance sources have been reported but have had limited commercial use; these include the Ty-2 gene from $S$. habrochaites $\mathrm{S}$. Knapp \& D. M Spooner (Hanson et al. 2006; Ji et al. 2007b),

Table 1. Plants exhibiting tomato yellow leaf curl disease symptoms (symptomatic) or virus presence in young leaves (infected) relative to the total number of plants of several Solanum spp. accessions inoculated with an isolate of the Israel strain of Tomato yellow leaf curl virus (TYLCV-IL) ${ }^{\mathrm{a}}$

\begin{tabular}{llc}
\hline Solanum spp. & Accession & Symptomatic/infected/inoculated \\
\hline Solanum chilense & EELM-722 & $0 / 4 / 10$ \\
S. habrochaites & EELM-388 & $0 / 0 / 10$ \\
& EELM-889 & $0 / 0 / 10$ \\
& EELM-386 & $6 / 6 / 10$ \\
& EELM-392 & $7 / 8 / 10$ \\
S. neorickii & EELM-743 & $6 / 7 / 10$ \\
S. pennelli & EELM-893 & $10 / 10 / 10$ \\
S. arcanum & EELM-382 & $0 / 7 / 10$ \\
S. pimpinellifolium & EELM-127 & $4 / 10 / 10$ \\
S. lycopersicum & EELM-363 & $1 / 10 / 10$ \\
& 'Anastasia' F & $0 / 10 / 10$ \\
& 'Moneymaker' & $10 / 10 / 10$ \\
\hline
\end{tabular}

a Plants were inoculated with TYLCV-IL[ES:Alm:Pep:99] (database accession number AJ489258) (Morilla et al. 2005) by Agrobacterium tumefaciens-mediated inoculation. Plants were assessed at 45 days postinoculation for the presence of disease symptoms and for the presence of virus in newly emerged young leaves by tissue-blot hybridization. Anastasia $F_{1}$ and Moneymaker were used as resistant and susceptible controls, respectively.
Ty-3 and Ty-4 genes from S. chilense (Agrama and Scott 2006; Ji et al. 2007a, 2008), Ty-5 and other minor genes from S. peruvianum L. (Anbinder et al. 2009), and a recessive gene from an unknown origin derived from 'Tyking' $F_{1}$ (GarcíaCano et al. 2008). The combining (pyramiding) of genes from different sources is promising (Vidavski et al. 2008).

The substantial diversity of the begomovirus populations associated with TYLCD has probably resulted, at least in part, from recombination (Moriones et al. 2007). During mixed infections, recombinants with novel biological characteristics can emerge (Davino et al. 2009; García-Andrés et al. 2006; Monci et al. 2002) and eventually become prevalent on resistant plants because of their greater fitness (Monci et al. 2002; Zhou et al. 1997). Therefore, effective and durable control of TYLCD will depend on identifying additional resistance genes with different mechanisms. The combined use of resistance genes with different and complementary mechanisms should reduce the probability that resistance-breaking strains will emerge.

After screening tomato wild-relative accessions for TYLCD resistance, in the present work, we identified and characterized resistance to TYLCV-IL and related begomoviruses in the tomato relative $S$. habrochaites. The resistance is apparently controlled by one dominant and one recessive independent loci that impede systemic TYLCV-IL accumulation and symptom expression even under severe disease pressure. By means of chimeras constructed among TYLCD-associated viruses with contrasting behavior on resistant plants and point mutagenesis disrupting protein expression, the $\mathrm{C} 4$ protein was found to be the viral determinant for systemic infection. The possible mechanisms underlying this resistance are discussed.

\section{RESULTS}

\section{Screening tomato genotypes for TYLCD resistance.}

Germplasm was screened for TYLCD resistance under high disease pressure generated by natural infection in the field. In total, 85 tomato wild relative accessions were tested, including six $S$. arcanum Peralta; eight $S$. chilense; one $S$. chmielewskii (C. M. Rick, Kesicki, Fobes \& M. Holle) D. M. Spooner, G. J. Anderson \& R. K. Jansen; three S. corneliomulleri J. F. Macbr.; 18 S habrochaites; three $S$. huaylasense Peralta; eight S. neorickii (C. M. Rick, Kesicki, Fobes \& M. Holle) D. M. Spooner, G. J. Anderson \& R. K. Jansen; five S. pennellii Correll; 13 S. peruvianum; and 20 S. pimpinellifolium L.. Plants of the following 10 accessions did not exhibit TYLCD symptom or virus accumulation: $S$. chilense EELM-722; S. habrochaites EEML-386, EELM-388, EELM-392, and EELM-889; $S$. neorickii EELM-743; S. pennelli EELM-893; S. arcanum EELM-382; and S. pimpinellifolium EELM-127 and EELM363. Plants of these accessions were then further tested for resistance with controlled virus inoculations. Differences in the resistance behavior were observed after inoculation of TYLCVIL by means of Agrobacterium tumefaciens (agroinoculation) (Table 1). Susceptible plants (showing TYLCD symptoms and virus accumulation) were observed in accessions EELM-127, EELM-743, EELM-893, EELM-392, EELM-363, and EELM386, as well as in the 'Moneymaker' tomato control. However, only EELM-893 and the control plants exhibited a homogenous susceptible response. Plants of EELM-382 and EELM-722 accumulated virus but were tolerant (Cooper and Jones 1983) (i.e., they did not show TYLCD symptoms). Interestingly, plants of two S. habrochaites accessions, EELM-889 and EELM-388, exhibited a consistent resistance (i.e., they did not support virus accumulation and did not show TYLCD symptoms). In these latter cases, virus accumulation could not be detected in young tissues of any tested plant, even by polymerase chain reaction (PCR) (Fig. 1). No symptomatic plants were observed in the 
commercial F1 hybrid 'Anastasia' used as resistant control, although all plants exhibited virus accumulation. Therefore, EELM-889 and EELM-388 were selected for detailed study.

\section{Plants of accessions EELM-388 and EELM-889 are resistant but not immune to TYLCV.}

Plants of accessions EELM-388 and EELM-889 were tested for TYLCV-IL resistance using three methods of experimental inoculation (Table 2). When agroinoculation was used, all plants were symptomless but a few plants accumulated virus. This variability in virus accumulation was probably associated with the genetic variability present in seed lots; such variability occurs because $S$. habrochaites is self-incompatible and requires intercrossing for maintenance (Peralta and Spooner 2005). When B. tabaci was used for inoculation, no plants were symptomatic or infected. When grafting onto infected Moneymaker rootstocks was used for inoculation, virus accumulation was detected in all plants up to 60 days after grafting

Table 2. Plants exhibiting tomato yellow leaf curl disease symptoms (symptomatic) or virus presence in young leaves (infected) relative to the total number of plants inoculated with an isolate of the Israel strain of Tomato yellow leaf curl virus (TYLCV-IL) following different inoculation procedures $^{\mathrm{a}}$

\begin{tabular}{lccc}
\hline & \multicolumn{3}{c}{ Symptomatic/infected/inoculated } \\
\cline { 2 - 4 } Genotype & Agroinoculation & Bemisia tabaci & Grafting \\
\hline EELM-388 & $0 / 1 / 36$ & $0 / 0 / 12$ & $0 / 18 / 18$ \\
EELM-889 & $0 / 4 / 36$ & $0 / 0 / 12$ & $0 / 19 / 19$ \\
'Moneymaker' & $36 / 36 / 36$ & $12 / 12 / 12$ & $11 / 11 / 11$ \\
\hline
\end{tabular}

a Plants were inoculated with TYLCV-IL[ES:Alm:Pep:99] (database accession number AJ489258) (Morilla et al. 2005) by Agrobacterium tumefaciens-mediated inoculation (results are from three independent inoculation experiments), by B. tabaci-mediated inoculation (using 30 viruliferous whiteflies per plant) or by grafting onto TYLCV-IL-infected Moneymaker tomato plants. Viruliferous whiteflies were obtained by providing healthy B. tabaci biotype Q adult individuals a 48-h acquisition access period on Moneymaker plants previously infected with TYLCV-IL by agroinoculation. Plants were assessed at 45 days after inoculation or grafting for the presence of disease symptoms and for the presence of virus in newly emerged young leaves by tissue-blot hybridization. Moneymaker was used as susceptible control. (last sampling time). Even under these latter conditions, no TYLCD-like symptoms were observed in any EELM-388 or EELM-889 plants, whereas all control Moneymaker scions exhibited severe symptoms and virus accumulation. Apical cuttings from the infected, top scions of grafted plants were rooted, and young tissues were sampled at several dates after rooting to check for virus persistence by tissue blot hybridization. Whereas virus was detected in all Moneymaker plants 60 days after cuttings were rooted, virus was not detected in half of the EELM-388 and EELM-889 plants, suggesting that they had recovered from infection (Fig. 2).

\section{EELM-388 and EELM-889 resistance is stable} under high disease pressure.

Results obtained when grafting was used for inoculation suggest that breakdown of resistance could occur under high

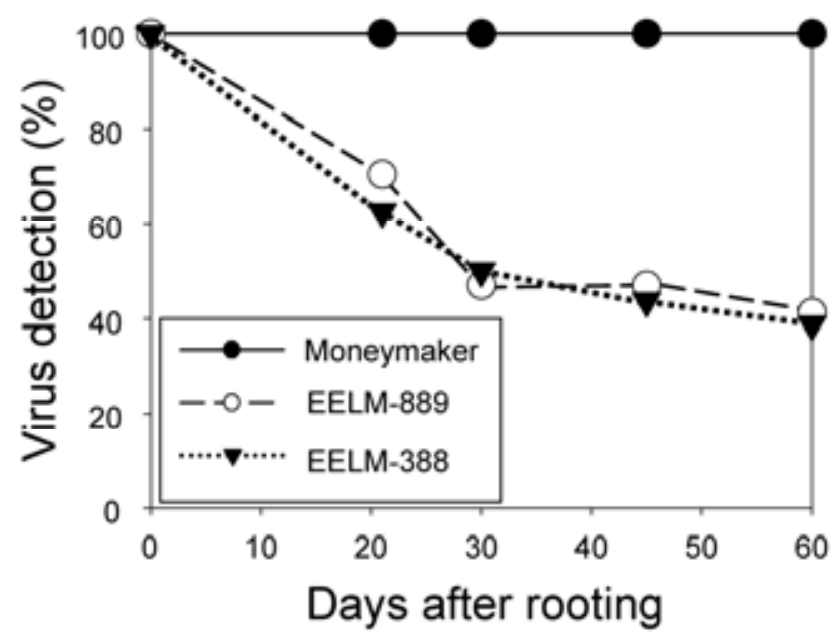

Fig. 2. Percentage of apical cuttings from 'Moneymaker', EELM-388, and EELM-889 scions infected with an isolate of the Israel strain of Tomato yellow leaf curl virus (TYLCV-IL) by grafting onto TYLCV-IL-infected Moneymaker rootstocks that retained virus after being detached from the rootstock and rooted. Virus was detected in young tissues by tissue blot hybridization at several dates after rooting.

\section{EELM-388}

MM

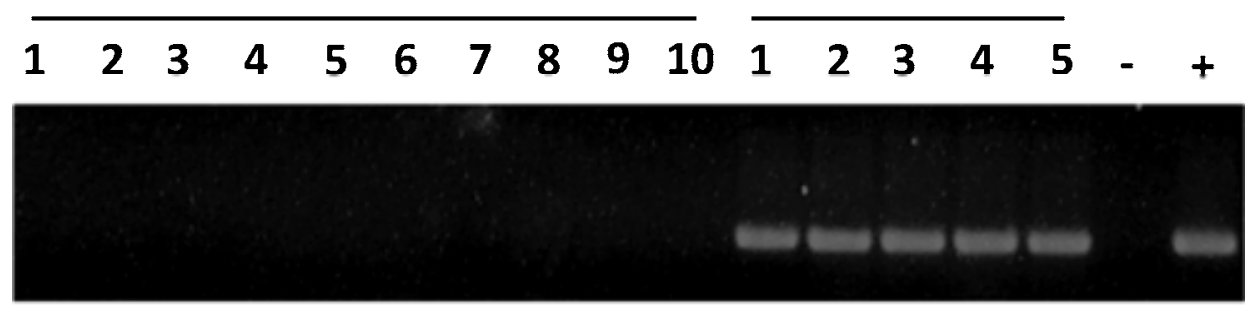

EELM-889

MM

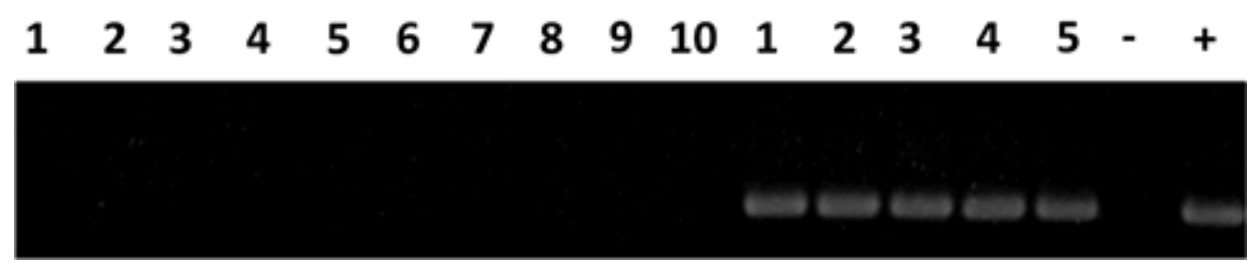

Fig. 1. Polymerase chain reaction detection of Tomato yellow leaf curl virus (TYLCV) in EELM-388 and EELM-889 plants. Analyses were performed at 45 days postinoculation in young tissues of 10 EELM-388 and EELM-889 plants, and five randomly-selected control 'Moneymaker' (MM) plants agroinoculated with an isolate of the Israel (IL) strain of TYLCV. Controls from healthy (-) and TYLCV-IL-infected (+) MM plants were included. 
disease pressure. Therefore, EELM-388 and EELM-889 were tested in controlled conditions with low and high viruliferous vector pressure (30 and 1,000 viruliferous B. tabaci whiteflies per test plant, respectively). Regardless of vector pressure, none of the EELM-388 or EELM-889 plants exhibited TYLCD symptoms or virus infection whereas nearly all Moneymaker plants were infected and symptomatic (Table 3). Similar results were obtained when plants were exposed to extremely high and natural TYLCD disease pressure in the field (Table 3).

\section{Inheritance of resistance to TYLCV-IL in EELM-889.}

The inheritance of resistance to TYLCV-IL in EELM-889 was further studied in an EELM-889 $\times$ Moneymaker genetic family under controlled agroinoculation conditions. As expected, neither symptoms nor virus accumulation were observed in EELM-889 plants whereas all Moneymaker plants exhibited severe symptoms and virus accumulation (Table 4). $F_{1}$ plants exhibited uniform resistance (they lacked symptoms and virus accumulation), indicating that resistance was a dominant trait. As expected for a dominant resistance trait, only the $\mathrm{F}_{2}$ and the backcross to the susceptible parent $\left(\mathrm{BC}_{1} \mathrm{~S}\right)$ generations showed segregation. In both populations, virus accumulation was detected in all symptomatic plants and was not detected in any of the asymptomatic plants. This perfect match between the two resistance characters strongly indicated that symptom expression and virus accumulation have a common genetic control. An alternative but less probable explanation would be that distinct genes governing symptom expression and virus accumulation are closely linked.
Based on the simplest hypothesis of common genetic control, resistant/susceptible ratios in the segregating populations (Table 4) fitted well to a model in which the resistance is tightly associated with two independent loci, one dominant and another recessive. The model of a single, dominant resistance locus was not supported by segregation numbers in the $\mathrm{F}_{2}$ generation (data not shown). Seven $\mathrm{F}_{3}$ families obtained from $\mathrm{F}_{2}$ susceptible plants were analyzed for TYLCV-IL re-

Table 5. Susceptible and resistant plants (exhibiting symptoms and virus accumulation or not) of each population for plants inoculated with an isolate of the Israel strain of Tomato yellow leaf curl virus (TYLCV-IL) ${ }^{\mathrm{a}}$

\begin{tabular}{lccc}
\hline & \multicolumn{3}{c}{ Number of plants } \\
\cline { 2 - 4 } Population & Tested & Resistant & Susceptible \\
\hline F $_{3}$ families & & & \\
2 & 7 & 0 & 7 \\
4 & 18 & 2 & 16 \\
6 & 13 & 0 & 13 \\
7 & 12 & 0 & 12 \\
14 & 12 & 10 & 2 \\
82 & 28 & 0 & 1 \\
102 & 12 & 11 & 12 \\
'Moneymaker' & 12 & 0 & 0 \\
EELM-889-2-selfed & 12 & 12 & 28 \\
\hline
\end{tabular}

a Plants were inoculated with TYLCV-IL[ES:Alm:Pep:99] (database accession number AJ489258) (Morilla et al. 2005) by Agrobacterium tumefaciens-mediated inoculation and assessed at 45 days postinoculation for presence of disease symptoms and for presence of virus in newly emerged young leaves by tissue-blot hybridization.

Table 3. Plants with the Israel (IL) or Mild (Mld) strain of Tomato yellow leaf curl virus (TYLCV) in young leaves (infected) or with tomato yellow leaf curl disease symptoms (symptomatic) relative to the total number of plants subjected to Bemisia tabaci-mediated inoculation (inoculated) in controlled conditions with low- or high-pressure inoculation (Low or High, respectively) or in open-field conditions with high disease pressure (Field) ${ }^{\mathrm{a}}$

\begin{tabular}{|c|c|c|c|c|c|}
\hline \multirow[b]{3}{*}{ Genotype } & \multicolumn{5}{|c|}{ Symptomatic/infected/inoculated } \\
\hline & \multicolumn{2}{|c|}{ TYLCV-IL } & \multicolumn{2}{|c|}{ TYLCV-Mld } & \multirow[b]{2}{*}{ Field } \\
\hline & High & Low & High & Low & \\
\hline EELM-388 & $0 / 0 / 6$ & $0 / 0 / 10$ & $0 / 0 / 6$ & $0 / 0 / 10$ & $0 / 0 / 10$ \\
\hline EELM-889 & $0 / 0 / 6$ & $0 / 0 / 10$ & $0 / 0 / 6$ & $0 / 0 / 10$ & $0 / 0 / 10$ \\
\hline 'Moneymaker' & $6 / 6 / 6$ & $9 / 9 / 10$ & $6 / 6 / 6$ & $10 / 10 / 10$ & $10 / 10 / 10$ \\
\hline
\end{tabular}

${ }^{\text {a }}$ For controlled virus inoculations, viruliferous whiteflies were obtained by providing healthy $B$. tabaci biotype Q adult individuals a 48 -h acquisition access period on Moneymaker plants previously infected with an isolate of either the IL or Mld strains of TYLCV by Agrobacterium tumefaciens-mediated inoculation, using the infectious clones of TYLCV-IL[ES:Alm:Pep:99] (database accession number AJ489258) and TYLCV-Mld[ES:72:97] (accession number AF071228) (Navas-Castillo et al. 1999; Morilla et al. 2005), respectively. For low-pressure inoculation, 30 viruliferous whiteflies were given a 48-h inoculation access period on test plants using clip-on cages and were then eliminated by insecticide treatment. For high-pressure inoculation, 1,000 viruliferous B. tabaci whiteflies per test plant were released inside wooden boxes covered with a whitefly-proof net in four successive applications of 250 viruliferous whiteflies on day $0,3,5$, and 7 and were then maintained on plants for two additional days before being eliminated by insecticide treatment. Plants were assessed at 45 days after inoculation or field transplant for the presence of disease symptoms and for the presence of virus in newly emerged young leaves by tissue-blot hybridization. Moneymaker was used as susceptible control.

Table 4. Segregation data for the Israel strain of Tomato yellow leaf curl virus (TYLCV-IL) resistance in populations derived from EELM-889

\begin{tabular}{|c|c|c|c|c|c|c|}
\hline \multirow[b]{2}{*}{ Generation } & \multirow[b]{2}{*}{ Total $^{\mathrm{c}}$} & \multicolumn{2}{|c|}{ Observed } & \multirow[b]{2}{*}{ Expected R:S ratio ${ }^{d}$} & \multicolumn{2}{|c|}{ Goodness of fit ${ }^{b}$} \\
\hline & & Symptomatic & Infected & & $\chi^{2}$ & $P$ \\
\hline EELM-889-2-selfed & 36 & 0 & 0 & $1: 0$ & $\ldots$ & $\ldots$ \\
\hline 'Moneymaker' (MM) & 71 & 71 & 71 & $0: 1$ & $\ldots$ & $\ldots$ \\
\hline $\mathrm{F}_{1}(\mathrm{MM} \times \mathrm{EELM}-889-2)$ & 108 & 0 & 0 & $1: 0$ & $\ldots$ & $\ldots$ \\
\hline $\mathrm{BC}_{1} \mathrm{R}\left(\mathrm{F}_{1} \times\right.$ EELM-889-2) & 108 & 0 & 0 & $1: 0$ & $\ldots$ & $\ldots$ \\
\hline $\mathrm{BC}_{1} \mathrm{~S}\left(\mathrm{MM} \times \mathrm{F}_{1}\right)$ & 223 & 101 & 101 & $1: 1$ & 1.978 & 0.159 \\
\hline $\mathrm{F}_{2}$ & 359 & 62 & 62 & $13: 3$ & 0.518 & 0.472 \\
\hline
\end{tabular}

a Data show the number of plants with virus in young leaves (Infected) or with tomato yellow leaf curl disease symptoms (Symptomatic) relative to the total number of plants inoculated. Plants were inoculated with TYLCV-IL[ES:Alm:Pep:99] (database accession number AJ489258) (Morilla et al. 2005) by Agrobacterium tumefaciens-mediated inoculation. Plants were assessed at 45 days postinoculation for the presence of disease symptoms and for the presence of virus in newly emerged young leaves by tissue-blot hybridization.

${ }^{\mathrm{b}}$ Goodness of fit is shown for the segregation ratio expected from a model in which resistance is controlled by two independent loci, one dominant and one recessive.

c Total number of plants.

${ }^{\mathrm{d}} \mathrm{R}=$ resistant and $\mathrm{S}=$ susceptible. 
sistance to confirm this genetic control. Plants of four $F_{3}$ families exhibited a uniform susceptible response but segregation was detected in the remaining three $\mathrm{F}_{3}$ families (Table 5). Presence of resistant plants in the progenies of susceptible plants confirmed the existence of at least one additional recessive factor in addition to the dominant resistance locus, as was suggested by the segregation numbers in the $F_{2}$.

An allelism test was used to compare the resistance in EELM-889 with that provided by the $T y-1$ gene (line TQ-159). Susceptible plants were observed within the $\mathrm{F}_{2}$ generation (Table 6), which demonstrates that resistance loci in EELM-889 differ from that of the $T y-1$ gene.

\section{Range of EELM-889 resistance.}

The stability and durability of a viral resistance strongly depends on the range of disease-associated viruses it is able to control. When agroinoculated with TYLCV-IL and four additional TYLCD-associated begomovirus species and strains reported in the Mediterranean basin (the Mild strain of TYLCV [TYLCV-Mld], the Spain strain of Tomato yellow leaf curl Sardinia virus [TYLCSV-ES], Tomato yellow leaf curl Málaga virus [TYLCMalV], and Tomato yellow leaf curl Axarquía virus [TYLCAxV]), EELM-889 consistently suppressed TYLCD symptom expression (Table 7). Systemic virus accumulation, however, differed among the viruses tested. Thus, no systemic infection occurred with TYLCV-IL and TYLCAxV, except for a few plants, which is attributable to genetic variability within seed lots (see above), whereas systemic infection occurred with TYLCSV-ES, TYLCV-Mld, and TYLCMalV. Therefore, EELM-889 exhibited a wide range of tolerance to all TYLCDassociated viruses tested and specific resistance against TYLCV-IL and its related recombinant species, TYLCAxV (García-Andrés et al. 2006). Although efficient systemic virus accumulation was observed in resistant plants agroinoculated with TYLCV-Mld, no such accumulation was detected when the plants were inoculated using $B$. tabaci, even under high inoculation pressure (Table 3).

Table 6. Susceptible plants (with symptoms) and resistant plants (without symptoms) for each population of plants inoculated with an isolate of the Israel strain of Tomato yellow leaf curl virus (TYLCV-IL) ${ }^{\mathrm{a}}$

\begin{tabular}{lccc}
\hline & \multicolumn{3}{c}{ Number of plants } \\
\cline { 2 - 4 } Population & Tested & Resistant & Susceptible \\
\hline EELM-889-2-selfed & 20 & 20 & 0 \\
TQ-519 & 20 & 20 & 0 \\
$\mathrm{~F}_{1}$ & 20 & 20 & 0 \\
$\mathrm{~F}_{2}$ & 94 & 73 & 21 \\
'Moneymaker' & 20 & 0 & 20 \\
\hline
\end{tabular}

${ }^{a}$ Plants were inoculated with TYLCV-IL[ES:Alm:Pep:99] (database accession number AJ489258) (Morilla et al. 2005) by Agrobacterium tumefaciens-mediated inoculation and were observed at 45 days postinoculation for the presence of disease symptoms.
EELM-889 resistance to TYLCV-IL operates by restricting virus systemic infection.

The capability of TYLCV-IL to replicate and accumulate in inoculated tissues of EELM-889 plants was investigated. Southern blot analysis of the viral DNA forms present in total DNA extracts obtained from agroinfiltrated leaf patches indicated that, like TYLCV-Mld, TYLCV-IL replicated and accumulated locally in both Moneymaker and EELM-889 plants (Fig. 3A). Therefore, these data suggest that restriction to TYLCV-IL accumulation in EELM-889 plants is expressed after initial infection and during systemic invasion.

\section{A small region of the TYLCV genome contains the determinant for viral DNA accumulation in newly emerged leaves of EELM-889.}

The contrasting ability of TYLCV-IL (and its recombinant relative TYLCAxV) and TYLCV-Mld (and its recombinant relative TYLCMalV) to accumulate systemically in agroinoculated EELM-889 plants (Table 7) made it possible to identify the region of the viral genome contributing to this differential behavior. The main difference in the genomes resides in a region of approximately 900 nucleotides which contains the 5' half of the IR and the 5' end of the Rep coding region, with the complete overlapped C4 ORF (we will henceforth refer to this as IRC region) (Fig. 4). Although TYLCV-IL and TYLCV-Mld differ in this region (Navas-Castillo et al. 2000), additional punctual mutation differences exist in the homologous part of their genomes, and some result in nonconservative amino acid changes. Therefore, to locate more precisely the determinant associated with the differences in virus accumulation, we conducted symmetrical genome exchanges involving the IRC region between TYLCV-IL and TYLCV-Mld. Two chimeras were constructed: chimera Q8 comprises the IRC from TYLCV-IL in a TYLCV-Mld background, and chimera Q9 comprises the IRC region from TYLCV-Mld in a TYLCV-IL background (Fig. 4). Partial direct repeat constructs of Q8 and Q9 were introduced into Moneymaker and EELM-889 plants by agroinfiltration. Similarly to TYLCV-Mld and TYLCV-IL, in Moneymaker plants at 30 days postinoculation (dpi), severe TYLCD symptoms were observed for both Q8 and Q9, and virus was detected in noninoculated tissue by tissue blot hybridization. In EELM-889 plants at 30 dpi, however, TYLCV-Mld and Q9 but not TYLCV-IL or Q8 caused systemic infection (Fig. 5A). Southern blot hybridization analysis of agroinfiltrated patches revealed the presence of viral DNA of either Q8 or Q9 in Moneymaker and EELM-889 (Fig. 3B), indicating that local accumulation was not impaired for Q8 in EELM-889. Therefore, these results are consistent with the inference that region IRC of the genome of TYLCV-IL likely contains the avirulence determinant of the resistance to systemic infection of EELM-889 plants. Putting the equivalent sequence of TYLCV-Mld in a TYLCV-IL background allows the virus to evade the resistance.

Table 7. Plants exhibiting tomato yellow leaf curl disease symptoms (symptomatic) or virus presence in young leaves (infected) relative to the total number of plants inoculated (inoculated) by Agrobacterium tumefaciens-mediated inoculation with isolates of the Israel or Mild strain of Tomato yellow leaf curl virus (TYLCV-IL or -Mld, respectively), the Spain strain of Tomato yellow leaf curl Sardinia virus (TYLCSV-ES), Tomato yellow leaf curl Málaga virus (TYLCMalV), and Tomato yellow leaf curl Axarquía virus (TYLCAxV)a

\begin{tabular}{lcccc}
\hline & & & Symptomatic/infected/inoculated \\
\cline { 2 - 5 } Genotype & TYLCV-IL & TYLCV-MId & TYLCSV-ES & TYLCMalV \\
\hline 'Moneymaker' & $30 / 30 / 30$ & $30 / 30 / 30$ & $30 / 30 / 30$ & $30 / 30 / 30$ \\
EELM-889 & $0 / 3 / 30$ & $0 / 29 / 30$ & $0 / 18 / 30$ & $0 / 26 / 30$ \\
\hline
\end{tabular}

${ }^{a}$ Plants were inoculated by A. tumefaciens-mediated inoculation using the following infectious clones: TYLCSV-ES[ES:Mur1:92] (database accession number Z25751), TYLCV-Mld[ES:72:97] (accession number AF071228), TYLCV-IL[ES:Alm:Pep:99] (accession number AJ489258), TYLCMalV [ES:421:99] (accession number AF271234), and TYLCAxV[ES:Alg:00] (accession number AY227892) (García-Andres et al. 2006; Monci et at. 2002; Morilla et al. 2005; Navas-Castillo et al. 1999; Noris et al. 1994). Plants were assessed at 45 days postinoculation for the presence of disease symptoms and for the presence of virus in newly emerged young leaves by tissue-blot hybridization. 
Disrupting expression of the $\mathrm{C} 4$ protein affects viral systemic invasion of EELM-889 plants.

To define more precisely the viral factor involved in overcoming the restriction to systemic viral infection in EELM889 , we made a point mutation in the C4 ORF to disrupt $\mathrm{C} 4$ expression in the created Q9 chimera. This mutation introduced a stop codon at the ninth position of the C4 ORF but did not alter the amino acid sequence of the overlapping Rep protein. Like Q9, the C4-deficient Q9 mutant was able to induce efficient systemic infection in agroinfiltrated Moneymaker plants (Fig. 5B); in contrast to Q9, the C4-deficient Q9 mutant did not induce TYLCD symptoms at $20 \mathrm{dpi}$ in Moneymaker plants and induced only mild symptoms at later times, suggesting that this protein is essential for symptom expression. In EELM-889 plants, however, systemic virus accumulation was impaired for the C4-deficient Q9 mutant but not for Q9 (Fig. 5B); no symptoms were observed in any case in plants of the accession EELM-889. A few EELM-889 plants exhibited accumulation of the C4-deficient Q9 mutant, although the hybridization signal was relatively weak. The $\mathrm{C} 4$ mutation was maintained in the progeny virus in all the systemically infected tissues, as verified by direct sequencing of PCR-amplified products. Therefore, these results indicated that $\mathrm{C} 4$ expression was required for efficient systemic infection of EELM-889 by Q9.

\section{TYLCV-MId requires C4 protein expression}

to overcome the resistance of EELM-889.

The importance of the C4 protein for the ability of TYLCMld to overcome the resistance of EELM-889 plants was studied. A C4-deficient TYLCV-Mld mutant was obtained with a stop codon at the ninth position of the C4 ORF that had no effect on the amino acid sequence of the overlapping Rep protein (Fig. 4, bottom). This mutant was able to systemically infect agroinfiltrated Moneymaker plants (Fig. 6A), although with delayed and attenuated TYLCD symptoms; these results again indicated that the $\mathrm{C} 4$ protein was involved in symptom expression in Moneymaker plants. In EELM-889 plants, however, this mutant caused systemic infection in only 1 of 12 inoculated plants (Fig. 6A). The mutation was maintained in the progeny virus in the systemically infected tissues, as verified
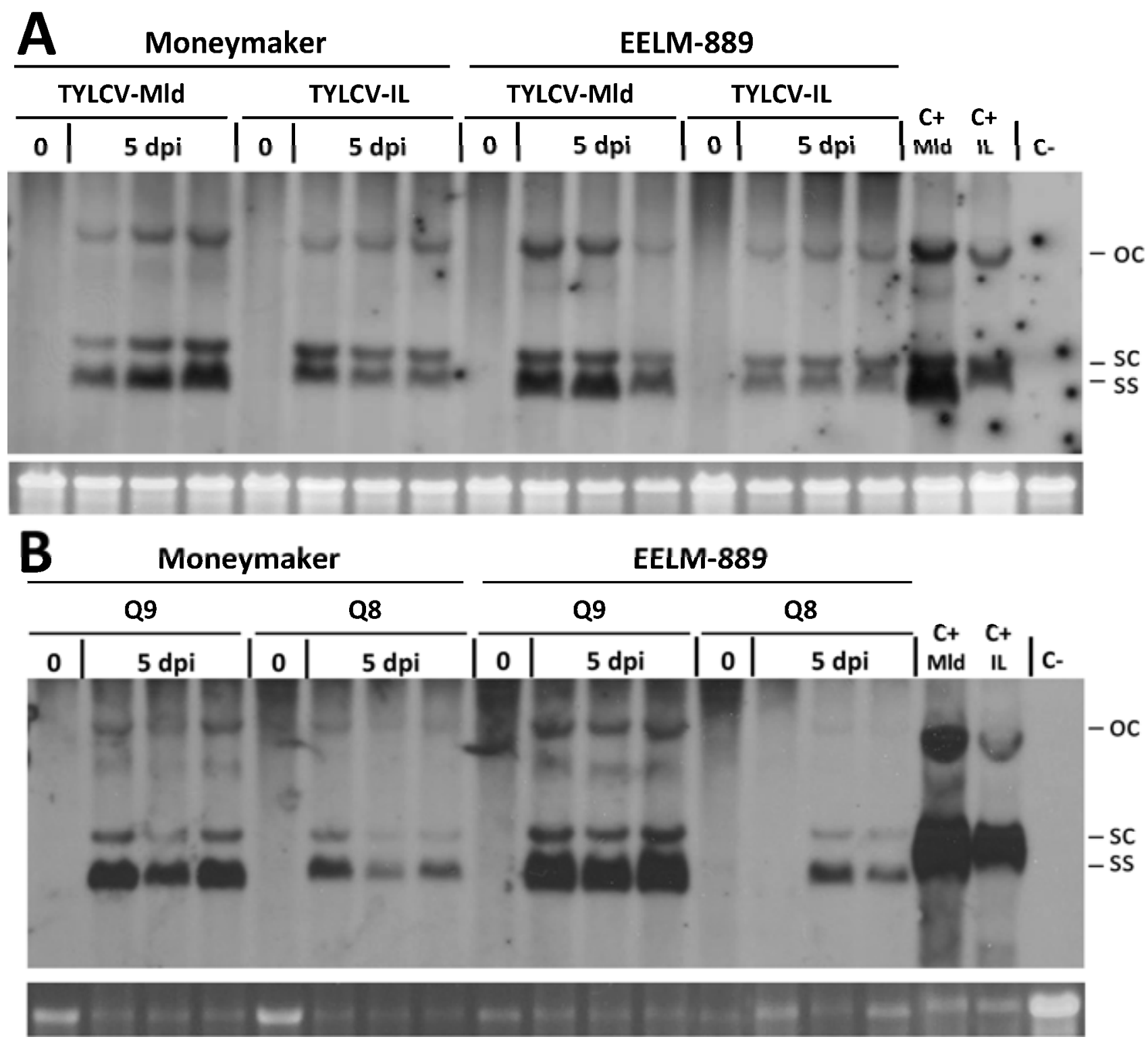

Fig. 3. Southern blot analysis of DNA extracted (at 0 and 5 days postinfiltration [dpi]) from 'Moneymaker' and EELM-889 leaves agroinfiltrated with infectious clones of Tomato yellow leaf curl virus (TYLCV). A, Mild (Mld) or Israel (IL) strains of TYLCV or B, chimeras (Q8 and Q9). Controls from healthy (C-), TYLCV-IL-infected (C+IL), or TYLCV-Mld-infected (C+Mld) Moneymaker plants were included; positions are indicated for the single-stranded genomic DNA (ss) and for the open circular (oc) and supercoiled (sc) double-stranded DNA forms of TYLCV DNA. 
by direct sequencing of PCR amplified products. Southern blot analysis of the viral DNA forms in agroinfiltrated leaf patches revealed that the $\mathrm{C} 4$-deficient TYLCV-Mld mutant accumulated locally in Moneymaker and EELM-889 plants in a manner similar to that of TYLCV-Mld (Fig. 6B). Therefore, these results demonstrated that the ability of TYLCV-Mld to systemically infect EELM-889 plants depends on the expression of the $\mathrm{C} 4$ protein.

\section{DISCUSSION}

Damage caused by TYLCD-associated viruses is increasing worldwide, and only limited resources are available to control epidemics (Lapidot and Friedman 2002; Moriones et al. 2011). Therefore, more robust and durable methods for controlling these viruses are needed. The development of such methods requires the identification of additional sources of commercially useful virus resistance and a better understanding of the resistance mechanisms. Here, we report on the identification and characterization of resistance sources from the tomato relative $S$. habrochaites that are highly effective against TYLCV-IL, the most common TYLCD-associated virus (Duffy and Holmes 2007; Lefeuvre et al. 2010). A relatively simple genetic control was demonstrated in the $S$. habrochaites accession EELM-889 that will facilitate the breeding of virusresistant cultivars. The study shows that the resistance loci differ from that of the $T y$ - 1 -associated resistance commonly deployed in commercial tomato cultivars, thus making it possible to provide improved resistance to TYLCD by gene pyramidization (Vidavski et al. 2008). The novelty of this work is that the range, mechanism of action, and viral determinant associated with resistance were investigated. The resistance was shown to be effective to five distinct TYLCD-associated viruses, preventing symptom expression, although systemic infection could occur in some instances when agroinoculation was used to challenge the virus. By using chimeric and mutant expression constructs, the $\mathrm{C} 4$ protein was shown to be associated with the ability to result in effective systemic infection.

\section{EELM-889 resistance is controlled by two independent loci, one of which is dominant and the other recessive.}

One dominant and at least one additional recessive loci were shown to be tightly associated with resistance to TYLCV-IL in EELM-889 plants; these loci are independent. Dominant control of virus resistance traits in plants is common (Kang et al. 2005), and several dominant or partially dominant resistance genes for TYLCD have been reported such as Ty-1 (Zamir et al. 1994), Ty-2, and Ty-3 (Ji et al. 2007b). Like the resistance documented in the current study, $T y-1$ resistance restricts systemic infection by the virus (Michelson et al. 1994). Because the TYLCD resistance described here was not allelic to $T y-1$ resistance, these two kinds of resistance can be combined to minimize TYLCD damage, as has been suggested for other resistance sources (Vidavski et al. 2008). This is important because the $T y-1$ gene is the most frequently used in commercial cultivars and is less effective against TYLCV than TYLCSV, which also cause epidemics together with the former virus (García-Andrés et al. 2009); EELM-889 resistance, however, completely blocked systemic infection by TYLCV-IL. There-

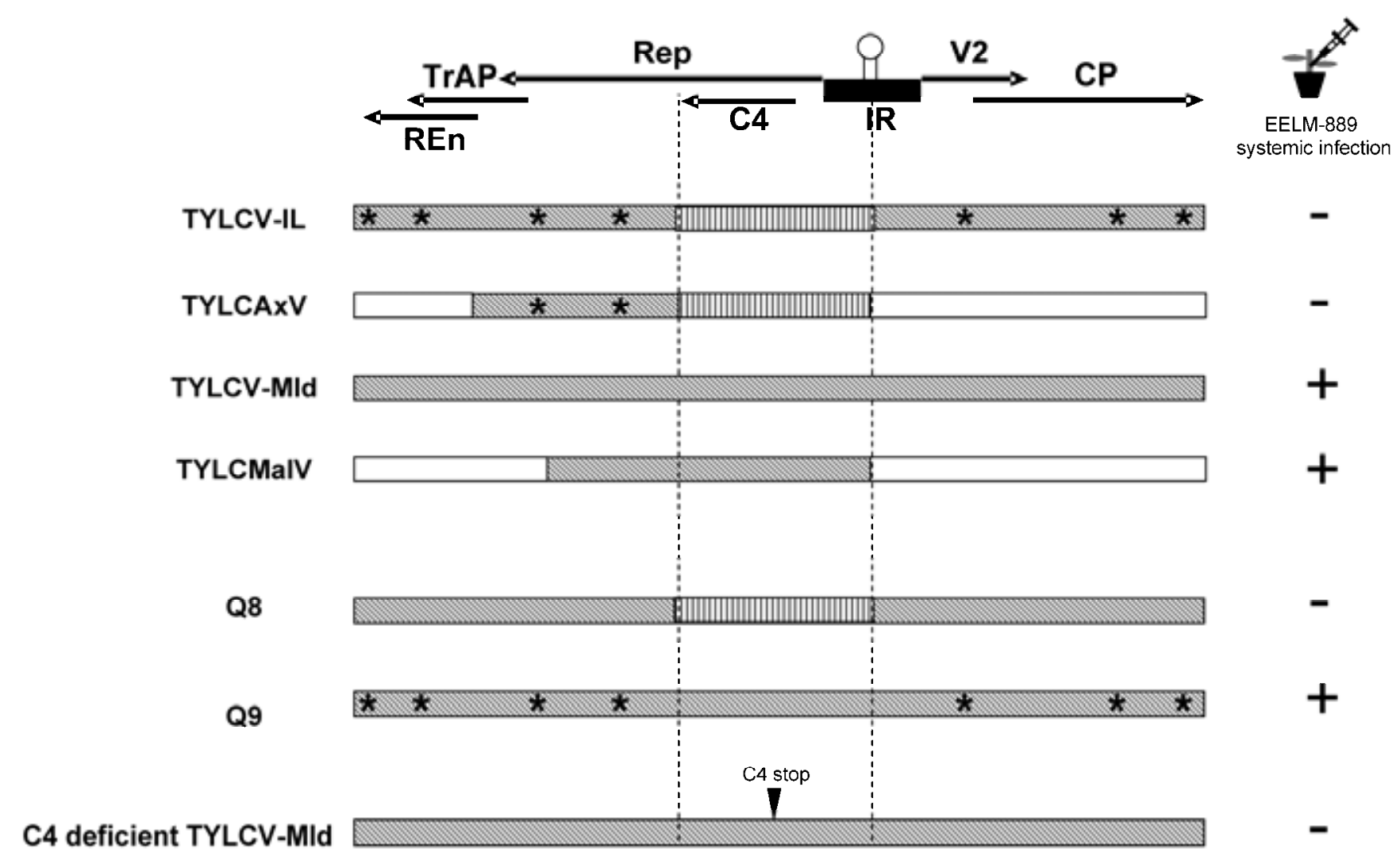

Fig. 4. Schematic representation of the genome structure of the Israel and Mild strains of Tomato yellow leaf curl virus (TYLCV-IL and TYLCV-Mld, respectively), natural recombinants Tomato yellow leaf curl Málaga virus and Tomato yellow leaf curl Axarquía virus (TYLCMalV and TYLCAxV, respectively), and engineered chimeric and mutant constructs of TYLCV strains and their ability to infect systemically plants of accession EELM-889. A genetic map showing the genes for coat (CP), precoat (V2), C4, replication-associated (Rep), transcriptional activator (TrAP), and replication enhancer (Ren) proteins, with the intergenic region (IR) shown at the top. Homologous genomic stretches between viral genotypes are shown as similarly shaded boxes, with asterisks indicating location of nonsynonymous nucleotide punctual differences in the homologous region of TYLCV-IL and TYLCV-Mld. The C4 point mutation is shown as a triangle. Outcome of infection in EELM-889 plants is indicated on the right: $+=$ systemic infection and $-=$ no systemic infection at 30 days postinoculation. 
fore, the pyramiding of both resistance traits in a single cultivar will reduce losses due to TYLCD. It should be stressed that, in addition to the dominant locus, at least one additional independent recessive resistance factor is evidently present in EELM-889. The involvement of recessive resistance loci that restrict systemic infection has been reported for begomoviruses such as Tomato leaf curl virus (Bian et al. 2007) and even for TYLCD-associated viruses (García-Cano et al. 2008). In our case, the individual contribution of each locus to the resistance is unknown and requires additional research. For this research, both resistance loci must be introgressed separately in the same tomato genetic background, which is currently underway in our laboratory.

\section{Consistent resistance to the widespread TYLCD-causing} begomovirus TYLCV-IL and tolerance to TYLCV-MId.

The resistance found in EELM-889 provided a broad tolerance to the TYLCD disease and strain-specific resistance to viruses causing this disease present in the Mediterranean basin. A consistent resistance to TYLCV-IL was observed, which is important because of the widespread occurrence of this virus (Abhary et al. 2007; Duffy and Holmes 2007; Lefeuvre et al. 2010; Moriones et al. 2011). Although agroinoculation can sometimes overcome virus resistance in some wild tomato relatives (Kheyr-Pour et al. 1994), this was not the case for resistance against TYLCV-IL in EELM-889. In contrast to TYLCV-IL, TYLCV-Mld achieved systemic infection of EELM-889 plants after agroinoculation, although symptoms were not observed. This contrasting behavior between these two closely related TYLCV strains (Navas-Castillo et al. 2000) after agroinoculation of EELM-889 plants helped us to study aspects of the plant-virus interaction because it obviated the need for B. tabaci-mediated inoculations and, therefore, eliminated the interference associated with plant-insect interactions (Mutschler and Wintermantel 2006). Leaf agroinfiltration experiments demonstrated that accumulation of TYLCV-IL at local infection sites was not impaired in EELM-889 plants, suggesting that, in these conditions, the resistance occurred during the systemic infection process (Ueki and Citovski 2007). However, the plant defense operating in EELM-889 against TYLCV-IL was overwhelmed when the virus was continuously supplied by grafting EELM-889 plants onto infected susceptible plants; a similar phenomenon has been reported with other plant viruses (Canto and Palukaitis 2001). Nevertheless, progressive recovery from virus infection occurred once TYLCV-IL-infected EELM-889 scions were detached from infected rootstocks and rooted (Fig. 2). This might suggest that, in the absence of a continuous virus influx, plant defenses (Chellapan et al. 2004; Waterhouse et al. 2001) operating in resistant plants can exclude TYLCV-IL from newly developing tissues. The triggering of plant host-silencing machinery by geminiviruses leading to disease recovery has been documented (Carrillo-Tripp et al. 2007; Chellapan et al. 2004, 2005). However, geminiviruses can, in some cases, overcome this host defense by virtue of their encoding suppressor proteins which inhibit silencing (Bisaro 2006; Vanitharani et al.

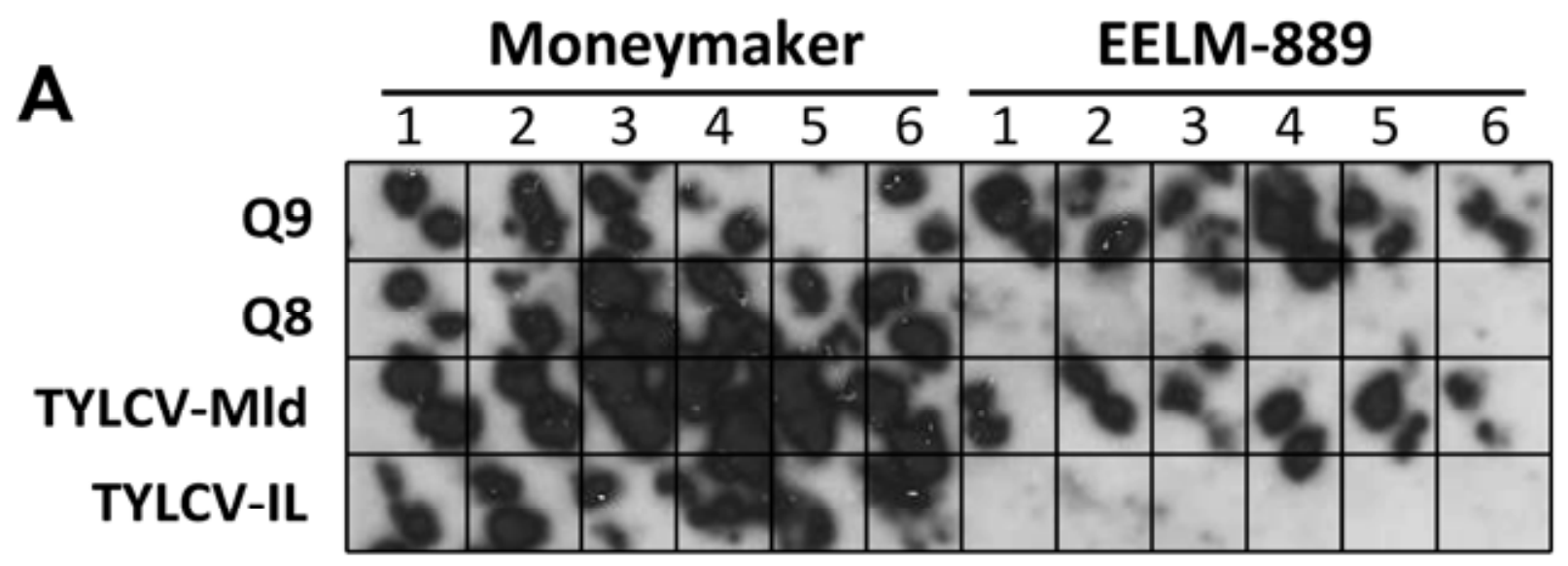

B

Moneymaker

EELM-889

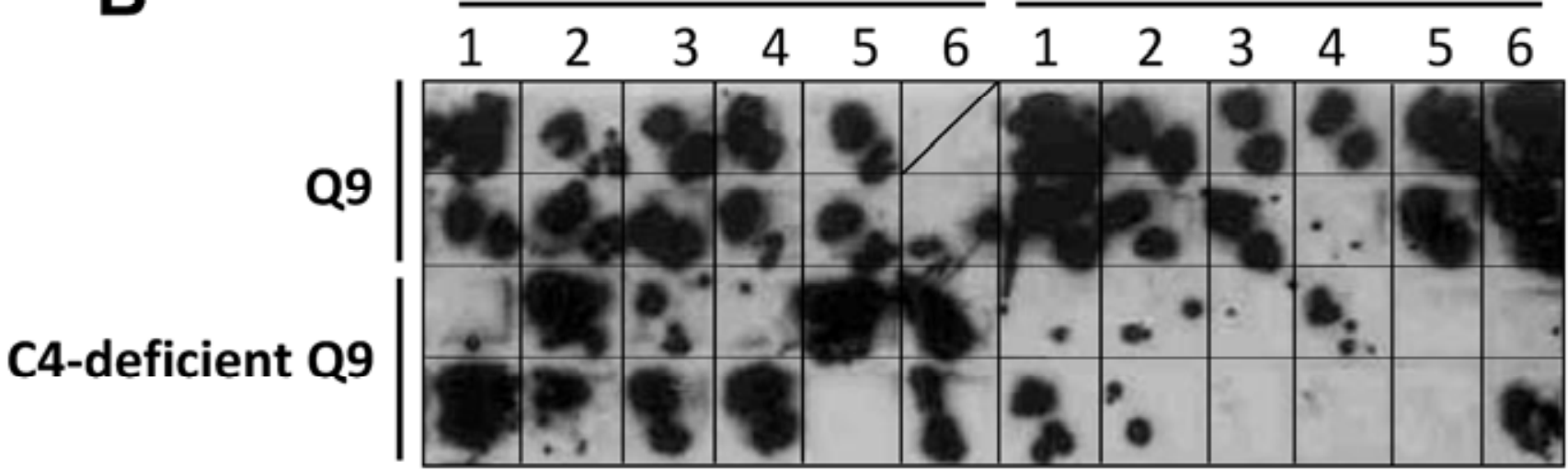

Fig. 5. Detection of virus in newly emerged young leaves by hybridization analysis of tissue blots of petiole cross sections at 30 days postinoculation. Hybridization results for 'Moneymaker' and EELM-889 plants agroinoculated with A, isolates of the Israel and Mild strains of Tomato yellow leaf curl virus (TYLCV-IL and TYLCV-Mld, respectively), and chimeric viruses Q8 and Q9 and B, Q9 and the C4-deficient Q9 mutant were obtained by using a DNA probe of TYLCV that detects all viruses inoculated; / indicates no sample presence. 
2005; Zrachya et al. 2007). Therefore, systemic virus infection will depend on the equilibrium between silencing and suppression of silencing (Seal et al. 2006; Voinnet 2005), which could differ between TYLCV-IL and TYLCV-Mld.

In addition to host defense and viral counter-defense, other processes like those affecting virus movement could affect virus systemic infection (Decroocq et al. 2009; Ueki and Citovski 2007). Therefore, we cannot rule out that the impairment of TYLCV-IL systemic infection in EELM-889 plants can also be due to a restriction of viral movement, and that such restriction is overcome by grafting on susceptible plants, as has been shown for other plant-virus interactions (Wintermantel et al. 1997). The finding of C4 as the possible determinant of systemic virus infection (see below) and the involvement of this protein in the movement of TYLCD-associated viruses (Jupin et al. 1994; Rojas et al. 2001) supports our contention that the resistance in EELM-889 can act at the level of virus movement.

Differences in the ability of TYLCV-IL and TYLCV-MId to systemically infect EELM-889 plants after agroinoculation suggest that the two viruses differ in their ability to overcome plant restrictions. However, neither virus was able to overcome resistance and spread systemically in EELM-889 plants when inoculated using B. tabaci, which suggests that TYLCV-Mld might require a high virus load (Moury et al. 2007) to overcome the restriction of resistant plants. Because B. tabaci is a phloem feeder and TYLCV is phloem limited, an alternative explanation is that vector resistance in EELM-889 plants may impair vector access to the phloem (Mutschler and Wintermantel 2006), impairing transmission; this explanation can be rejected, however, because $B$. tabaci readily acquires TYLCVMld from agroinfected EELM-889 plants and transmits the virus to susceptible Moneymaker plants (results not shown).

\section{Dissection of the TYLCV genome: the $\mathrm{C} 4$ protein as a viral determinant \\ of systemic infection of resistant plants.}

The viral region IRC was determined to be responsible for the differential ability of TYLCV-IL and TYLCV-Mld to systemically infect EELM-889 plants. This region contains key elements for virus replication such as those present in the $5^{\prime}$-IR or in the encoded N-terminal part of the Rep protein (Jeske 2009). Restriction of virus replication, however, does not seem to be central to EELM-889 resistance in our experimental conditions because both viruses replicated and accumulated locally (i.e., at the inoculation site). However, we cannot rule out some local effect of A. tumefaciens. One could argue that the local performance of chimera Q8 was slightly affected, and that this could be associated with impaired systemic spread in resistant plants; however, a similar local effect that did not disrupt systemic accumulation was observed in Moneymaker plants (Fig. 3). It seems plausible that the impairment in EELM-889 plants might occur during systemic infection. Based on previous research, we suspected the possible involvement of the $\mathrm{C} 4$ protein, because it is a multifunctional protein that, in TYLCDassociated viruses, has been involved in virus movement (Jupin et al. 1994; Rojas et al. 2001). In monopartite begomoviruses, it is also a pathogenicity determinant (Gopal et al. 2007; Jupin et al. 1994; Krake et al. 1998; Ridgen et al. 1994; Selth et al. 2004) and, similar to the related AC4 protein of bipartite begomoviruses, acts as suppressors of RNA-silencing (Dogra et al. 2009; Sharma et al. 2010; Vanitharani et al. 2005). Therefore, we examined whether $C 4$ could be responsible for the differing abilities of TYLCV-IL and TYLCV-Mld to infect systemically EELM-889 plants. The exchange of a region comprising this protein between these viruses in chimeras Q8 and Q9 supports this hypothesis. Also, C4 disruption im-
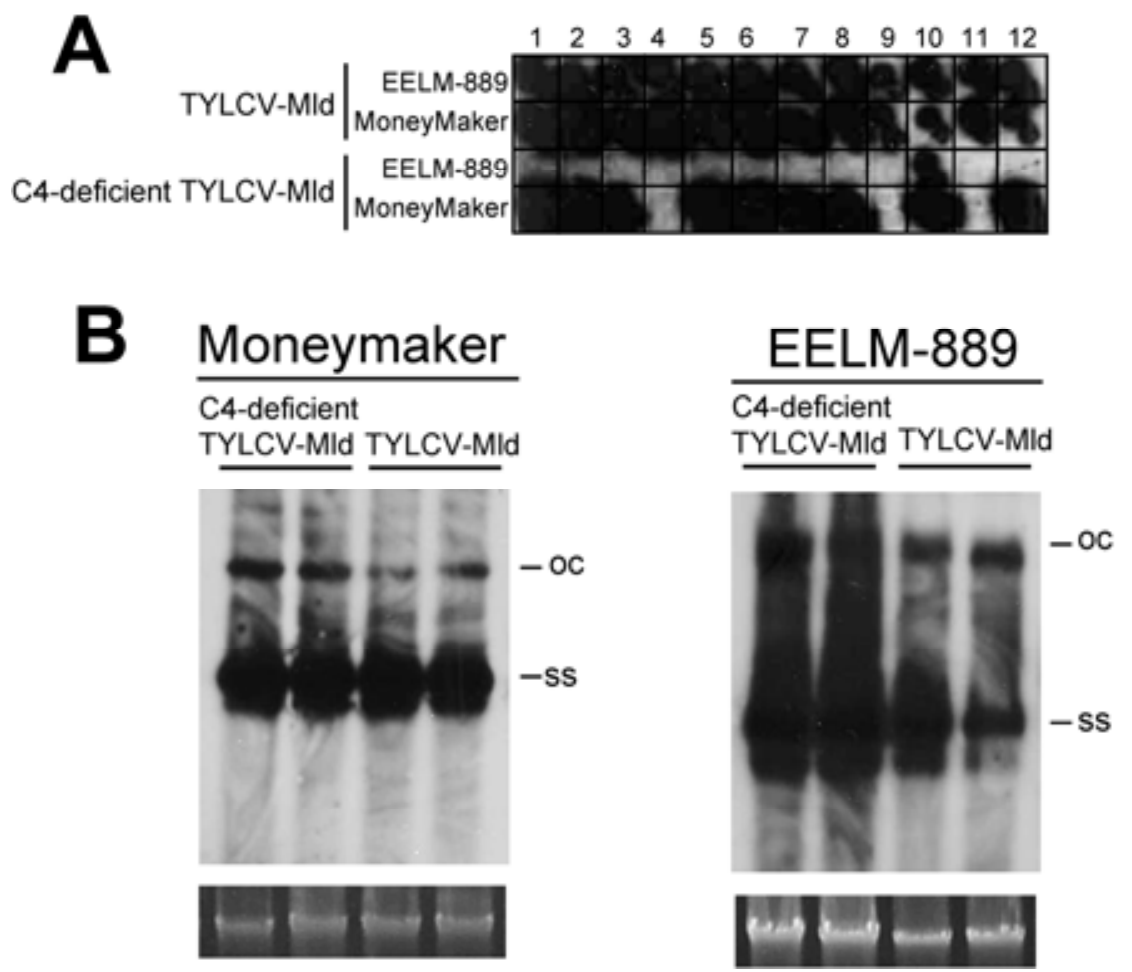

Fig. 6. Detection of Tomato yellow leaf curl virus (TYLCV) in agroinfiltrated patches and noninoculated tissues of 'Moneymaker' and EELM-889 plants. A, Tissue blot hybridization analysis of petiole cross sections of young noninoculated leaves of Moneymaker and EELM-889 plants agroinoculated with an isolate of the Mild strain TYLCV-Mld and the C4-deficient TYLCV-Mld at 30 days postinoculation (dpi). B, Southern blot analysis at 5 dpi of DNA extracts from inoculated patches of leaves of Moneymaker and EELM-889 plants agroinfiltrated with TYLCV-Mld and C4-deficient TYLCV-Mld; positions are indicated for the single-stranded genomic DNA (ss) and for the open circular (oc) double-stranded DNA forms of TYLCV DNA. 
paired systemic accumulation of TYLCV-Mld and chimera Q9 in EELM-889 plants. These results are consistent with the hypothesis that $\mathrm{C} 4$ is a viral determinant of systemic accumulation in EELM-889 plants.

\section{C4-mediated strategy to overcome resistance to systemic infection in EELM-889.}

In summary, our results suggest that resistance in EELM889 plants occurs during systemic invasion and that the $\mathrm{C} 4$ protein can play a role. This protein is the least conserved among geminiviruses and, as indicated before, it has multiple functions during virus infection. The amelioration of disease symptoms observed in Moneymaker plants when infected with the C4-deficient mutants of TYLCV-Mld and the Q9 chimera is consistent with its role as a pathogenicity factor. This is also supported by our observation that the heterologous expression of the C4 protein of TYLCV-Mld from the Potato virus $X$ (PVX) vector (Chapman et al. 1992) resulted in enhanced PVX accumulation and disease symptom severity in Nicotiana benthamiana plants (our unpublished data). Therefore, our results suggest that $\mathrm{C} 4$ is a pathogenicity determinant that is essential for counteracting virus restriction in EELM-889 plants. Further research is needed to determine why the C4 protein of TYLCV-Mld can counteract EELM889 viral restriction. The ability of viruses to suppress RNA silencing might determine their ability to systemically infect host plants (Asaoka et al. 2010). Thus, the differences observed between TYLCV-IL and TYLCV-Mld in EELM-889 plants might be due to differences in the ability of their $\mathrm{C} 4$ proteins to suppress RNA silencing. It is also possible that C4 of TYLCV-Mld permits systemic infection of EELM-889 plants by facilitating virus movement because $\mathrm{C} 4$ is involved with the movement of TYLCD-associated viruses (Jupin et al. 1994; Rojas et al. 2001). Therefore, the ability of C4 from TYLCV-Mld to overcome defense barriers in EELM-889 plants might result from the suppression of an antiviral response, the enhancement of viral movement, or both, as has been proposed for other pathogenicity determinants in other virus systems (Bayne et al. 2005; Cao et al. 2010; Yelina et al. 2002). A close connection between virus suppression of RNA silencing and systemic movement has been suggested (Díaz-Pendón and Ding 2008).

The results of this study indicate that resistance to TYLCV-IL in EELM-889 plants is controlled by a dominant and a recessive independent loci. Therefore, we cannot rule out the possibility that systemic infection of TYLCV-IL is prevented by the product of a putative dominant gene. This occurs, for example, for RTM genes of Arabidopsis thaliana against Tobacco etch virus (Decroocq et al. 2009). It can then be argued that, in EELM-889, the C4 from TYLCV-IL is recognized by the product from the resistance locus and its role in plant infection is neutralized, whereas C4 from TYLCVMld is not recognized and virus infection can progress. $\mathrm{C} 4$, however, should also interact with the resistance associated with the recessive locus. Therefore, C4 from TYLCV-Mld is able to complement the putative loss-of-susceptibility or counteract resistance responses that characterize recessive traits (Truniger and Aranda 2009). A clearer understanding of the mechanism underlying EELM-889 resistance requires further study. The testing of these hypotheses requires nearisogenic tomato lines in which the dominant and recessive loci have been separately introgressed. Introgression is currently underway in our laboratory, and the resulting tomato lines will be valuable for understanding how plant genes provide resistance to TYLCV and related viruses. These lines can also be used to isolate and characterize the resistance-associated genes.

\section{MATERIALS AND METHODS}

\section{General methods.}

Standard manipulations of nucleic acids and bacteria were performed according to protocols of Sambrook and associates (1989).

\section{Plant material and virus sources.}

The tomato wild relative accessions screened in this study were from the La Mayora-CSIC seed bank. In every assay, plants of Moneymaker (La Mayora-CSIC seed bank) were included as susceptible controls and, when needed, plants of the commercial $F_{1}$ hybrid Anastasia (Seminis Vegetable Seeds, Barcelona, Spain) were used as resistant controls. The TQ-519 breeding line (Zeta Seeds, Almería, Spain), which contains the Ty-1 dominant TYLCD-resistance gene in homozygosis, was also used in some experiments.

Self-compatibility studies on plants of accessions EELM388 and EELM-889 were conducted by fluorescence microscopy observation of pollen tube development (Kearns and Inouye 1993). These studies identified one self-compatible plant from EELM-889 (EELM-889-2), which was selfed to provide the seed needed for testing the resistant parent performance (EELM-889-2-selfed) and for crosses for genetic studies. The inheritance mode of the TYLCV resistance observed in EELM-889 was studied with a family of generations obtained from crosses made by hand pollination between the susceptible tomato Moneymaker and the resistant accession EELM-889. Pollen of the self-compatible EELM-889-2 plant was used to pollinate pistils from a single Moneymaker plant to obtain the interspecific $\mathrm{F}_{1}$ hybrid (Moneymaker $\times$ EELM889-2). A single $F_{1}$ plant was then self-pollinated to provide the $\mathrm{F}_{2}$ generation and was used to obtain backcrosses to the resistant $\left(\mathrm{F}_{1} \times \mathrm{EELM}-889-2, \mathrm{BC}_{1} \mathrm{R}\right)$ and to susceptible (Moneymaker $\left.\times \mathrm{F}_{1}, \mathrm{BC}_{1} \mathrm{~S}\right)$ parents. Also, a number of $\mathrm{F}_{3}$ progenies were derived by selfing selected $\mathrm{F}_{2}$ plants. An allelism test was performed in generations of a cross between EELM-889-2 and the breeding line TQ-519; the latter line was previously tested for TYLCV-IL resistance and was known to carry the $T y-1$ gene. In this case, the two parents, the $\mathrm{F}_{1}$ hybrid $(\mathrm{TQ}-519 \times$ EELM-889-2), and the corresponding $\mathrm{F}_{2}$ progeny were tested.

The following infectious clones of isolates of begomovirus species and strains associated with TYLCD have been described: TYLCSV-ES[ES:Mur1:92] (database accession number Z25751), TYLCV-Mld[ES:72:97] (accession number AF071228), TYLCV-IL[ES:Alm:Pep:99] (accession number AJ489258), TYLCMalV [ES:421:99] (accession number AF271234), and TYLCAxV[ES:Alg:00] (accession number AY227892) (García-Andrés et al. 2006; Monci et at., 2002; Morilla et al. 2005; Navas-Castillo et al. 1999; Noris et al. 1994). Chimeric viruses Q8 and Q9 were produced by exchanging the IR and the $5^{\prime}$ end of the Rep coding region containing the whole C4 ORF between the TYLCV-IL and TYLCVMld genomes. For Q8 construction, the TYLCV-IL[ES:Alm: Pep:99] IR and C4 ORF region were amplified by PCR using primers MA579 (5'-ATACTATTAGGTCTCCATGGC-3') and MA580 (5'-TCATTTAGAAGTGGATCCCAC-3'), introducing a BamHI cleavage site (underlined) (present in TYLCV-Mld but not in TYLCV-IL genomes). The PCR DNA product obtained was digested with Bam HI and NcoI and subcloned into pBluescript SK+ (pBSK+; Stratagene, La Jolla, CA, U.S.A.) along with a TYLCV-Mld BamHI-NcoI fragment lacking the IR and C4 ORF of TYLCV-Mld, derived from pSP72/97 (Navas-Castillo et al. 1999), to produce the pQ8 clone. A 1.7mer partial direct repeat construct of $\mathrm{Q} 8, \mathrm{p} 1.7 \mathrm{Q} 8$, was produced by subcloning the full-length BamHI insert of pQ8 into the unique BamHI site of a 0.7-mer clone previously obtained 
by a SmaI-SphI deletion in pSP72/97. The 1.7-mer fragment thus obtained in pBSK+ was released with HimdIII and SpeI and subcloned into the binary vector pBin19 (Bevan 1984) (using the $X b a I$ site, compatible with SpeI). This clone was transformed in Agrobacterium tumefaciens LBA4404, and its infectivity was confirmed on Moneymaker tomato plants. For Q9 construction, a nearly full-length genome of TYLCVIL[ES:Alm:Pep:99] (lacking the IR and C4 ORF) was amplified by PCR using primers MA1018 (5'-TGAACTTGAAGAG TGGGTCGC-3') and MA1019 (5'-CAATATGTGGGATCCAC TTCTAAATGA-3'), introducing a BamHI cleavage site (underlined) (present in TYLCV-Mld but not in TYLCV-IL genomes). The PCR DNA product obtained was digested with BamHI and NcoI and subcloned into pBSK+ along with a TYLCV-Mld BamHI-NcoI fragment containing the IR and C4 ORF of TYLCV-Mld derived from pSP72/97, to produce the pQ9 clone. A partial direct repeat construct of Q9, p1.4Q9, was produced by subcloning a full-length BamHI insert of pQ8 into the unique BamHI site of a 0.4-mer clone obtained by deletion of the XbaI-XbaI fragment of pQ9. The 1.4-mer fragment thus produced in pBSK+ was released with HindIII and ScaI and subcloned into the pBIN19 vector. This clone was transformed in A. tumefaciens LBA4404 and its infectivity was confirmed on Moneymaker tomato plants.

C4-deficient mutants of Q9 and TYLCV-Mld were obtained from the full-length clones by oligonucleotide-directed mutagenesis using a QuickChangeR XL site-directed mutagenesis kit (Stratagene), as described by Genovés and associates (2006), and with primers MA 651 (5'-GAATTTCCCTTC AAATTGGATCAGCACATGGAGATGTGGTTCC-3') and MA 652 (5'-GGAACCACATCTCCATGTGCTGATCCAATTTGA AGGGAAATTC-3') to create a stop codon on the ninth position of the $\mathrm{C} 4$ protein. Mutants do not alter the amino acid sequence of the overlapping Rep protein. Infectious clones were obtained with procedures described above.

\section{Virus inoculation.}

Germplasm was screened for TYLCD resistance under natural infection conditions in an open-field assay. The assay was conducted in Aguilas (Murcia, eastern coastal Spain) during summer, when B. tabaci numbers and TYLCD disease pressure were extremely high. Plants were transplanted into the field at the four-leaf growth stage. Each genotype was represented by one plot, which consisted of 10 contiguous plants in the same row. The within-row and between-row spacing was 0.6 and $1.5 \mathrm{~m}$, respectively. Plants in the plots were inspected for TYLCD symptoms 3 months after transplanting. Plants not exhibiting TYLCD-associated symptoms were analyzed for the presence of TYLCD-associated viruses in young leaves by tissue-blot hybridization (see below). Selected lines were also evaluated when needed in open plastic-house conditions during summer, under high TYLCD disease pressure.

For controlled virus inoculation, plants at the three-leaf growth stage were inoculated with the TYLCD-associated infectious clones by means of A. tumefaciens using the stem puncture method as described previously (Monci et al. 2005). Also, for local accumulation studies, leaf tissue agroinfiltration was conducted essentially as described by Davino and associates (2009), using A. tumefaciens infectious cultures. B. tabaci-mediated inoculations were performed as described (Monci et al. 2002) using 30 viruliferous whiteflies per test plant. Nonviruliferous $B$. tabaci biotype $\mathrm{Q}$ individuals were obtained from a colony reared on melon (Cucumis melo L. 'ANC42'; La Mayora-CSIC seedbank). Viruliferous whiteflies were obtained by providing $B$. tabaci adults with a 48 -h acquisition access period (AAP) on systemically infected young leaves of Moneymaker tomato plants agroinoculated 3 weeks earlier. After
AAP, whiteflies were transferred to healthy test plants (threeleaf growth stage) for a 48-h inoculation access period (IAP), and maintained using clip-on cages. After the IAP, insects were removed from plants, which were then treated with insecticide. When needed, extremely high-pressure inoculations were performed in insect-proof cages containing 1,000 viruliferous B. tabaci whiteflies per plant (three-leaf growth stage), which were applied in four successive batches $(250$ viruliferous whiteflies per batch) on day $0,3,5$, and 7; after the last application, plants were kept with whiteflies for two additional days before the whiteflies were eliminated by insecticide treatment. For graft inoculations, a stem piece containing a leaf with a bud from a healthy test plant was grafted onto a TYLCV-ILinfected Moneymaker rootstock plant. In every controlled inoculation assay, Moneymaker plants were used as susceptible controls. Controlled inoculation experiments were performed in a growth chamber $\left(25^{\circ} \mathrm{C}\right.$ day and $20^{\circ} \mathrm{C}$ night, $70 \%$ relative humidity, with a 16 -h photoperiod and photosynthetically active radiation at $250 \mu \mathrm{mol} \mathrm{s} \mathrm{m}^{-1}$ ), and the inoculated plants were kept in the growth chamber or in an insect-proof glasshouse with temperature control (approximately 16-h day length, at 22 to $27^{\circ} \mathrm{C}$ during the day and 17 to $20^{\circ} \mathrm{C}$ at night) and supplemental light when needed until analyzed.

\section{Virus detection.}

Virus was detected in inoculated plants by tissue-blot hybridization of freshly cross-sectioned leaf petioles or by Southern blot hybridization of DNA extracts performed according to Noris and associates (1998) and loading $1.2 \mu \mathrm{g}$ of total DNA per lane. Virus detection assays used a mixture of digoxigeninlabeled DNA probes (Navas-Castillo et al. 1999) able to recognize all TYLCD-associated viruses detected in the Mediterranean basin and chimeric viruses. When needed, TYLCV was detected by PCR using primers MA272 (5'-CTGAATGTTYG GATGGAAATGTGC-3', corresponding to nucleotides 2,353 to 2,376 of TYLCV-IL, of database accession number AJ489258) and MA274 (5'-GCTCGTAAGTTTCCTCAACGGAC-3', complementary to nucleotides 232 to 254 of TYLCV-IL, of accession number AJ489258); PCR conditions were as described by Monci and associates (2002). Also, if needed, symptom severity was rated on inoculated plants using an arbitrary scale: 0 (no symptoms), 1 (hardly visible symptoms), 2 (very mild symptoms), 3 (mild symptoms), 4 (moderate symptoms), and 5 (severe symptoms); plants that rated $>2$ on this scale were considered susceptible.

\section{Data analyses.}

Segregation for resistance was assessed using a Mendelian approach, grouping plants into resistant and susceptible classes. Segregation ratios were tested for goodness-of-fit to theoretical ratios for the hypothesis that two independent loci, one dominant and one recessive, control the resistance, and $\chi^{2}$ tests were performed on the segregating populations using numerical data.

\section{ACKNOWLEDGMENTS}

This work was supported, in part, by grants AGL2007-66062-C02-01 (Ministerio de Ciencia, e Innovación, Spain, co-financed by Fondo de Desarrollo Regional [FEDER]), IDEA 130278D (Junta de Andalucía, Spain, co-financed by FEDER), and CDTI 2004-2006 number 05-0004 (Ministerio de Ciencia, e Innovación, Spain). D. M. Tomás and C. C. Cañizares contributed equally to this work. M. C. Cañizares was financed by the former grant, and D. M. Tomás completed this research as part of his Ph.D. degree and was recipient of a fellowship from the Ministerio de Educación y Ciencia. We thank E. R. Bejarano for providing the infectious clone of TYLCV-IL, J. P. T. Valkonen for helpful discussion and critical reading of the manuscript, B. Jaffee for manuscript editing, and M. V. Martín and R. Campos for technical assistance. 


\section{LITERATURE CITED}

Abhary, M., Patil, B., and Fauquet, C. 2007. Molecular biodiversity, taxonomy, and nomenclature of tomato yellow leaf curl-like viruses. Pages 85-118 in: Tomato Yellow Leaf Curl Virus Disease. Management, Molecular Biology, Breeding for Resistance. H. Czosnek, ed. Springer, Dordrecht, The Netherlands.

Agrama, H. A., and Scott, J. W. 2006. Quantitative trait loci for Tomato yellow leaf curl virus and Tomato mottle virus resistance in tomato. J. Am. Hortic. Sci. 131:267-272.

Anbinder, I., Reuveni, M., Azari, R., Paran, I., Nahon, S., Shlomo, H., Chen, L., Lapidot, M., and Levin, I. 2009. Molecular dissection of Tomato leaf curl virus resistance in tomato line TY172 derived from Solanum peruvianum. Theor. Appl. Genet. 119:519-530.

Antignus, Y., Nestel, D., Cohen, S., and Lapidot, M. 2001. Ultravioletdeficient greenhouse environment affects whitefly attraction and flightbehavior. Environ. Entomol. 30:394-399.

Argüello-Astorga, G. R., Guevara-González, R. G., Herrera-Estrella, L R., and Rivera-Bustamante, L. R. 1994. Geminivirus replication origins have a group-specific organization of iterative elements: A model for replication. Virology 203:90-100.

Asaoka, R., Shimura, H., Arai, M., and Masuta, C. 2010. A progeny virus from a cucumovirus pseudorecombinant evolved to gain the ability to accumulate its RNA-silencing suppressor leading to systemic infection in tobacco. Mol. Plant-Microbe Interact. 23:332-339.

Bayne, E. H., Rakitina, D. V., Morozov, S. Y., and Baulcombe, D. C. 2005. Cell to cell movement of potato potexvirus $\mathrm{X}$ is dependent on suppression of RNA silencing. Plant J. 44:471-482.

Bevan, M. 1984. Binary vectors for plant transformation. Nucleic Acids Res. 12:8711-8721.

Bian, X. Y., Thomas, M. R., Rasheed, M. S., Saeed, M., Hanson, P., De Barro, P. J., and Rezaian, M. A. 2007. A recessive allele (tgr-1) conditioning tomato resistance to geminivirus infection is associated with impaired viral movement. Phytopathology 97:930-937.

Bisaro, D. M. 2006. Silencing suppression by geminivirus proteins. Virology 344:158-168.

Cahill, M., Gorman, K., Day, S., Denholm, I., Elbert, A., and Nauen, R. 1996. Baseline determination and detection of resistance to imidacloprid in Bemisia tabaci (Homoptera: Aleyrodidae). Bull. Entomol. Res. 86:343-349.

Canto, T., and Palukaitis, P. 2001. A Cucumber mosaic virus (CMV) RNA 1 transgene mediates suppression of the homologous viral RNA 1 constitutively and prevents CMV entry into the phloem. J. Virol. 75:9114-9120.

Cao, M., Ye, X., Willie, K., Lin, J., Zhang, X., Redinbaugh, M. G., Simon, A. E., Morris, T. J., and Qu, F. 2010. The capsid protein of Turnip crinkle virus overcomes two separate defense barriers to facilitate systemic movement of the virus in Arabidopsis. J. Virol. 84:7793-7802.

Carrillo-Tripp, J., Lozoya-Gloria, E., and Rivera-Bustamante, R. F. 2007. Symptom remission and specific resistance of pepper plants after infection by Pepper golden mosaic virus. Phytopathology 97:51-59.

Castillo, A. G., Collinet, D., Deret, S., Kashoggi, A., and Bejarano, E. R. 2003. Dual interaction of plant PCNA with geminivirus replication accesory protein (Ren) and viral replication protein (Rep). Virology 312:381-394.

Chapman, S., Kavanagh, T., and Baulcombe, D. 1992. Potato virus X as a vector for gene expression in plants. Plant J. 2:549-557.

Chellapan, P., Vanitharani R., and Fauquet C. M. 2004. Short interfering RNA accumulation correlates with host recovery in DNA virus-infected hosts, and gene silencing targets specific viral sequences. J. Virol. 78:7465-7477.

Chellapan, P., Vanitharani R., Ogbe R., and Fauquet C. M. 2005. Effect of temperature on geminivirus-induced RNA silencing in plants. Plant Physiol. 138:1828-1841.

Cohen, S., and Lapidot, M. 2007. Appearance and expansion of TYLCV: A historical point of view. Pages 3-12 in: Tomato Yellow Leaf Curl Virus Disease. Management, Molecular Biology, Breeding for Resistance. H. Czosnek, ed. Springer, Dordrecht, The Netherlands.

Cooper, J. I., and Jones, A. T. 1983. Responses of plants to viruses: Proposals for the use of terms. Phytopathology 73:127-128.

Czosnek, H., Ghanim, M., and Ghanim, M. 2002. The circulative pathway of begomoviruses in the whitefly vector Bemisia tabaci-insights from studies with Tomato yellow leaf curl virus. Ann. Appl. Biol. 140:215-231.

Davino, S., Napoli, C., Dellacroce, C., Miozzi, L., Noris, E., Davino, M., and Accotto, G. P. 2009. Two new natural begomovirus recombinants associated with the Tomato yellow leaf curl disease co-exist with parental viruses in tomato epidemics in Italy. Virus Res. 143:15-23.

Decroocq, V., Salvador, B., Sicard, O., Glasa, M., Cosson, P., SvanellaDumas, L., Revers, F., García, J. A. and Candresse, T. 2009. The determinant of potyvirus ability to overcome the RTM resistance of Arabidopsis thaliana maps to the $\mathrm{N}$-terminal region of the coat protein. Mol.
Plant-Microbe Interact. 22:1302-1311.

Díaz-Pendón, J. A., and Ding, S. W. 2008. Direct and indirect roles of viral suppressors of RNA silencing in pathogenesis. Annu. Rev. Phytopathol. 46:303-326.

Dogra, S. C., Eini, O., Rezaian, M. A., and Randles J. W. 2009. A novel shaggy-like kinase interacts with the Tomato leaf curl virus pathogenicity determinant C4 protein. Plant Mol. Biol. 71:25-38.

Duffy, S., and Holmes, E. C. 2007. Multiple introductions of the Old World begomovirus Tomato yellow leaf curl virus into the New World. Appl. Environ. Microbiol. 73:7114-7117.

Elbert, A., and Nauen, R. 2000. Resistance of Bemisia tabaci (Homoptera: Aleyrodidae) to insecticides in southern Spain with special reference to neonicotinoids. Pest Manage. Sci. 56:60-64.

Fauquet, C., Briddon, R., Brown, J., Moriones, E., Stanley, J., Zerbini, M., and Zhou, X. 2008. Geminivirus strain demarcation and nomenclature. Arch. Virol. 153:783-821.

García-Andrés, S., Monci, F., Navas-Castillo, J., and Moriones E. 2006. Begomovirus genetic diversity in the native plant reservoir Solanum nigrum: Evidence for the presence of a new virus species of recombinant nature. Virology 350:433-442.

García-Andrés, S., Accotto, G. P., Navas-Castillo, J., and Moriones, E. 2007. Founder effect, plant host, and recombination shape the emergent population of begomoviruses that cause the tomato yellow leaf curl disease in the Mediterranean basin. Virology 359:302-312.

García-Andrés, S., Tomás, D.M., Navas-Castillo, J., and Moriones. 2009. Resistance-driven selection of begomoviruses associated with the tomato yellow leaf curl disease. Virus Res. 146:66-72.

García-Cano, E., Resende, R. O., Boiteux, L. S., Giordano, L. B., Fernández-Munoz, R., and Moriones, E. 2008. Phenotypic expression, stability, and inheritance of a recessive resistance to monopartite begomoviruses associated with tomato yellow leaf curl disease in tomato. Phytopathology 98:618-627.

Genovés, A., Navarro, J. A., and Pallás, V. 2006. Functional analysis of the five Melon necrotic spot virus genome-encoded proteins. J. Gen. Virol. 87:2371-2380.

Glick, E., Zrachya, A., Levy, Y., Mett, A., Gidoni, D., Belausov, E., Citovsky, V., and Gafni, Y. 2008. Interaction with host SGS3 is required for suppression of RNA silencing by Tomato yellow leaf curl virus V2 protein. Proc. Nat. Acad. Sci. U.S.A. 105:157-161.

Gopal, P., Kumar, P. P., Sinilal, B., Jose, J., Yadunandam, A. K.., and Usha, R. 2007. Differential roles of C4 and beta C1 in mediating suppression of post-transcriptional gene silencing: Evidence for transactivation by the $\mathrm{C} 2$ of Bhendi yellow vein mosaic virus, a monopartite begomovirus. Virus Res. 123:9-18.

Gutiérrez, C. 1999. Geminivirus DNA replication. Cell Mol. Life Sci. 56:313-329.

Hanley-Bowdoin, L., Settlage, S. B., Orozco, B. M., Nagar, S., and Robertson, D. 2000. Geminiviruses: Models for plant DNA replication, transcription, and cell cycle regulation. Crit. Rev. Biochem. Mol. Biol. 35:105-140.

Hanson, P. M., Green, S. K., and Kuo, G. 2006. Ty-2, a gene on chromosome 11 conditioning geminivirus resistance in tomato. Tomato Genet. Crop Rep. 56:17-18.

Hanssen, I. M., Lapidot, M., and Thomma, B. P. H. 2010. Emerging viral diseases of tomato crops. Mol. Plant-Microbe Interact. 23:539-548.

Jeske, H. 2009. Geminiviruses. Curr. Top. Microbiol. Immunol. 331:185226.

Ji, Y., Schuster D. J., and Scott J. W. 2007a. Ty-3, a begomovirus resistance locus near the Tomato yellow leaf curl virus resistance locus Ty-1 on chromosome 6 of tomato. Mol. Breed. 20:271-284.

Ji, Y., Scott, J. W., Hanson, P., Graham, E., and Maxwell, D. P. 2007b. Sources of resistance, inheritance and location of genetic loci conferring resistance to members of the tomato infecting begomovirues, Pages 343-362. in: Tomato Yellow Leaf Curl Virus Disease. Management, Molecular Biology, Breeding for Resistance. H. Czosnek, ed. Springer, Dordrecht, The Netherlands.

Ji, Y., Scott, J. W., Maxwell, D. P., and Schuster, D. J. 2008. Ty-4, a Tomato yellow leaf curl virus resistance gene on chromosome 3 of tomato. Rep. Tomato Genet. Coop. 58:29-31.

Jupin, I., Dekouchkovsky, F., Jouanneau, F., and Gronenborn, B. 1994. Movement of tomato yellow leaf curl geminivirus (TYLCV): Involvement of the protein encoded by ORF C4. Virology 204:82-80.

Kang, B. C., Yeam, I., and Jahn, M. M. 2005. Genetics of plant virus resistance. Annu. Rev. Phytopathol. 43:581-621.

Kearns, C. A., and Inouye, D. W. 1993. Techniques for Pollination Biologists. University Press of Colorado, Niwot.

Kheyr-Pour, A., Gronenborn, B., and Czosnek, H. 1994. Agroinoculation of tomato yellow leaf curl virus (TYLCV) overcomes the virus-resistance of wild Lycopersicon species. Plant Breed. 112:228-233.

Krake, L. R., Rezaian, M. A., and Dry, I. B. 1998. Expression of the 
tomato leaf curl geminivirus $\mathrm{C} 4$ gene produces virus like symptoms in transgenic plants. Mol. Plant-Microbe Interact. 11:413-417.

Lapidot, M., and Friedmann, M. 2002. Breeding for resistance to whiteflytransmitted geminiviruses. Ann. Appl. Biol. 140:109-127.

Laufs, J., Traut, W., Heyraud, F., Matzeit, V., Rogers, S. G., Schell, J., and Gronenborn, B. 1995. In vitro cleavage and joining at the viral origin of replication by the replication initiator protein of tomato yellow leaf curl virus. Proc. Natl. Acad. Sci. U.S.A. 92:3879-3883.

Lefeuvre, P., Martin, D. P., Harkins, G., Lemey, P., Gray, A. J. A., Meredith, S., Lakay, F., Monjane, A. R., Lett, J. M., Varsani, A., and Heydarnejad, J. 2010. The spread of Tomato yellow leaf curl virus from the Middle East to the world. PLoS Pathog. 6:e1001164.

Michelson, I., Zamir, D., and Czosnek, H. 1994. Accumulation and translocation of Tomato yellow leaf curl virus (TYLCV) in a Lycopersicon esculentum breeding line containing the L. chilense TYLCV tolerance gene Ty-1. Phytopathology 84:928-933.

Monci, F., Sánchez-Campos, S., Navas-Castillo, J., and Moriones, E. 2002. A natural recombinant between the geminiviruses Tomato yellow leaf curl Sardinia virus and Tomato yellow leaf curl virus exhibits a novel pathogenic phenotype and is becoming prevalent in Spanish populations. Virology 303:317-326.

Monci, F., García-Andrés, S., Maldonado, J. A., and Moriones, E. 2005. Resistance to monopartite begomoviruses associated with the bean leaf crumple disease in Phaseolus vulgaris controlled by a single dominant gene. Phytopathology 95:819-826.

Morilla, G., Janssen, D., Garcia-Andrés, S., Moriones, E., Cuadrado, I. M., and Bejarano, E. R. 2005. Pepper (Capsicum annuum) is a dead-end host for Tomato yellow leaf curl virus. Phytopathology 95:1089-1097.

Moriones, E., García-Andrés, S., and Navas-Castillo, J. 2007. Recombination in the TYLCV complex: A mechanism to increase genetic diversity. Implications for plant resistance development. Pages 119-138 in: Tomato Yellow Leaf Curl Virus Disease. Management, Molecular Biology, Breeding for Resistance. H. Czosnek, ed., Springer, Dordrecht, The Netherlands.

Moriones, E.,, Navas-Castillo, J., and Díaz-Pendón, J. A. 2011. Emergence of begomovirus diseases. Pages 301-320 in: Recent Advances in Plant Virology. C. Caranta, M. A. Aranda, M. Tepfer, and J. López-Moya., eds. Caister Academic Press, Norfolk, U.K.

Moury, B., Fabre, F., and Senoussi, R. 2007. Estimation of the number of virus particle transmitted by an insect vector. Proc. Natl. Acad. Sci. U.S.A. 104:17891-17896.

Mutschler, M. A., and Wintermantel, W. M. 2006. Reducing virus associated crop loss through resistance to insect vectors. Pages 241-260 in: Natural Resistance Mechanisms of Plant Viruses. G. Loebenstein and J. P. Carr, eds. Springer, Dordrecht, The Netherlands.

Navas-Castillo, J., Sánchez-Campos, S., Díaz, J. A., Sáez-Alonso, E., and Moriones, E. 1999. Tomato yellow leaf curl virus-Is causes a novel disease of common bean and severe epidemics in tomato in Spain. Plant Dis. 83:29-32

Navas-Castillo, J., Sánchez-Campos, S., Noris, E., Louro, D., Accotto, G. P., and Moriones, E. 2000. Natural recombination between Tomato yellow leaf curl virus-Is and Tomato leaf curl virus. J. Gen. Virol. 81:2791-2801.

Noris, E., Hidalgo, E., Accotto, G. P., and Moriones, E. 1994. High similarity among the tomato yellow leaf curl virus isolates from the West Mediterranean Basin-the nucleotide sequence of an infectious clone from Spain. Arch. Virol. 135:165-170.

Noris, E., Vaira, A. M., Caciagli, P., Masenga, V., Gronenborn, B., and Accotto, G. P. 1998. Amino acids in the capsid protein of Tomato yellow leaf curl virus that are crucial for systemic infection, particle formation, and insect transmission. J. Virol. 72:10050-10057.

Palumbo, J. C., Horowitz, A. R., and Prabhaker, N. 2001. Insecticidal control and resistance management for Bemisia tabaci. Crop Prot. 20:739-766.

Peralta, I. E., and Spooner, D. M. 2005. Morphological characterization and relationships of wild tomatoes (Solanum L. Section Lycopersicon). Monogr. Syst. Bot. Mo. Bot. Gard. 104:227-257.

Picó, B., Diez, M. J., and Nuez, F. 1996. Viral diseases causing the greatest economic losses to the tomato crop .2. The Tomato yellow leaf curl virus - a review. Sci. Hortic. 67:151-196.

Ridgen, J. E., Krake, L. R., Rezaian, M. A., and Dry, I. B. 1994. ORF C4 of Tomato leaf curl geminivirus is a determinant of symptom severity. Virology 204:847-850.

Rojas, M. R., Jiang H., Salati R., Xoconostle-Cazares B., Sudarshana M. R., Lucas W. J., and Gilbertson R. L. 2001. Functional analysis of pro- teins involved in movement of the monopartite begomovirus, Tomato yellow leaf curl virus. Virology 291:110-125.

Sambrook, J., Fritsch, E. F., and Maniatis, T. 1989. Molecular Cloning: A Laboratory Manual, 2nd ed. Cold Spring Harbor Laboratory Press, Cold Spring Harbor, NY, U.S.A.

Seal, S. E., Van den Bosch, F., and Jeger, M. J. 2006. Factors influencing begomovirus evolution and their increasing global significance: Implications for sustainable control. Crit. Rev. Plant Sci. 25:23-46.

Selth, L. A., Randles, J. W., and Rezaian, M. A. 2004. Host responses to transient expression of individual genes encoded by Tomato leaf curl virus. Mol. Plant-Microbe Interact. 17:27-33.

Sharma, P., Ikegami, M., and Kon, T. 2010. Identification of the virulence factors and suppressors of posttranscriptional gene silencing encoded by Ageratum yellow vein virus, a monopartite begomovirus. Virus Res. 149:19-27.

Trinks, D., Rajeswaran, R., Shivaprasad, P. V., Akbergenov, R., Oakeley, E. J., Veluthambi, K., Hohn, T., and Pooggin, M. M. 2005. Suppression of RNA silencing by a geminivirus nuclear protein, AC2, correlates with transactivation of host genes. J. Virol. 79:2517-2527.

Truniger, V., and Aranda, M. A. 2009. Recessive resistance to plant viruses. Adv. Virus Res. 75:119-159.

Ueki, S., and Citovsky, V. 2007. Spread throughout the plant: Systemic transport of viruses. Pages 85-118 in: Viral Transport in Plants. E. Waigmann and M. Heinlein, eds. Springer, Berlin/Heidelberg.

van Wezel, R., Dong, X., Blake, P., Stanley, J., and Hong, Y. 2002. Differential roles of geminivirus Rep and AC4 (C4) in the induction of necrosis in Nicotiana benthamiana. Mol. Plant Pathol. 3:461-471.

van Wezel, R., Dong, X. L., Liu, H. T., Tien, P., Stanley, J., and Hong, Y. G. 2002. Mutation of three cysteine residues in Tomato yellow leaf curl virus-China $\mathrm{C} 2$ protein causes dysfunction in pathogenesis and posttranscriptional gene-silencing suppression. Mol. Plant-Microbe Interact 15:203-208.

van Wezel, R., Liu, H., Tien, P., Stanley, J., and Hong, Y. 2001. Gene C2 of the monopartite geminivirus Tomato yellow leaf curl virus-China encodes a pathogenicity determinant that is localized in the nucleus. Mol. Plant-Microbe Interact. 14:1125-1128.

Vanitharani, R., Chellappan, P., and Fauquet, C. M. 2005. Geminiviruses and RNA silencing. Trends Plant Sci. 10:144-151.

Vidavski, F., Czosnek, H., Gazit, S., Levy, D., and Lapidot, M. 2008. Pyramiding of genes conferring resistance to Tomato yellow leaf curl virus from different wild tomato species. Plant Breed. 127:625-631.

Voinnet, O. 2005. Induction and suppression of RNA silencing: Insights from viral infections. Nat. Rev. Genet. 6:206-220.

Wartig, L., Kheyr-Pour, A., Noris, E., De Kouchkovsky, F., Jouanneau, F., Gronenborn, B., and Jupin I. 1997. Genetic analysis of the monopartite tomato yellow leaf curl geminivirus: Roles of V1, V2, and C2 ORFs in viral pathogenesis. Virology 228:132-140.

Waterhouse, P. M., Wang, M. B., and Lough, T. 2001. Gene silencing as an adaptive defence against. Nature 411:834-842.

Wege, C. 2007. Movement and localization of tomato yellow leaf curl viruses in the infected plant. Pages 185-206 in: Tomato Yellow Leaf Curl Virus Disease. Management, Molecular Biology, Breeding for Resistance. H. Czosnek, ed. Springer, Dordrecht, The Netherlands

Wintermantel, W. M., Banerjee, N., Oliver, J. C., Paolillo, D. J., and Zaitlin, M. 1997. Cucumber mosaic virus is restricted from entering minor veins in transgenic tobacco exhibiting replicase-mediated resistance. Virology 231:248-257.

Yelina, N. E., Savenkov, E. I., Solovyev, A. G., Morozov, S. Y., and Valkonen, J. P. T. 2002. Long-distance movement, virulence, and RNA silencing suppression controlled by a single protein in hordei- and potyviruses: Complementary functions between virus families. J. Virol. 76:12981-12991

Zamir, D., Ekstein-Michelson, I., Zakay, Y., Navot, N., Zeidan, M., Sarfatti, Y., Eshed, Y., Harel, E., Pleban, T., Van-Oss, H., Kedar, N., Rabinowitch, H. D., and Czosnek, H. 1994. Mapping and introgression of a tomato yellow leaf curl virus tolerance gene, Ty-1. Theor. Appl. Genet. 88:141-146.

Zhou, X. P., Liu, Y. L., Calvert, L., Muñoz, C., OtimNape, G. W., Robinson, D. J., and Harrison, B. D. 1997. Evidence that DNA-A of a geminivirus associated with severe cassava mosaic disease in Uganda has arisen by interspecific recombination. J. Gen. Virol. 78:2101-2111.

Zrachya, A., Glick, E., Levy, Y. Arazi, T., Citovsky, V., and Gafni, Y. 2007. Suppressor of RNA silencing encoded by Tomato yellow leaf curl virusIsrael. Virology 358:159-165. 